\title{
Rhizosphere bacteria are more strongly related to plant root traits than fungi in temperate montane forests: insights from closed and open forest patches along an elevational gradient
}

Article

Accepted Version

Merino-Martín, L., Griffiths, R. I., Gweon, H. S., FurgetBretagnon, C., Oliver, A., Mao, Z., Le Bissonnais, Y. and Stokes, A. (2020) Rhizosphere bacteria are more strongly related to plant root traits than fungi in temperate montane forests: insights from closed and open forest patches along an elevational gradient. Plant and Soil, 450 (1-2). pp. 183-200. ISSN 0032-079X doi: https://doi.org/10.1007/s11104-02004479-3 Available at https://centaur.reading.ac.uk/89885/

It is advisable to refer to the publisher's version if you intend to cite from the work. See Guidance on citing.

To link to this article DOI: http://dx.doi.org/10.1007/s11104-020-04479-3

Publisher: Springer

All outputs in CentAUR are protected by Intellectual Property Rights law, including copyright law. Copyright and IPR is retained by the creators or other copyright holders. Terms and conditions for use of this material are defined in 
the End User Agreement.

www.reading.ac.uk/centaur

\section{CentAUR}

Central Archive at the University of Reading

Reading's research outputs online 
1 Rhizosphere bacteria are more strongly related to plant root traits than fungi in

6 Luis Merino-Martín ${ }^{1,2,3}$, Robert I. Griffiths ${ }^{3}$, Hyun S. Gweon ${ }^{3,4}$, Clément Furget-Bretagnon ${ }^{1}$, $7 \quad$ Anna Oliver ${ }^{3}$, Zhun Mao ${ }^{1}$, Yves Le Bissonnais ${ }^{5}$, Alexia Stokes ${ }^{1}$.

8

9

\section{elevational gradient}

\section{Author list / address list:}

${ }^{1}$ University Montpellier, Amap, INRAE, Cirad, Cnrs, Ird, Montpellier, France.

${ }^{2}$ C.N.R.S., UMR CEFE, Montpellier, France.

${ }^{3}$ Centre for Ecology \& Hydrology, Crowmarsh Gifford, Wallingford, Oxfordshire, United Kingdom.

${ }^{4}$ Harborne Building, School of Biological Sciences, University of Reading, United Kingdom

${ }^{5}$ INRAE, UMR1221 LISAH, Montpellier, France.

"Corresponding author. Tel.: +33(0)789288168. E-mail address: luismerinomartin@ gmail.com (L. Merino-Martín).

For submission to Plant and Soil

Article type: Full paper.

\section{Word count:}

\begin{tabular}{|l|l|l|l|}
\hline $\begin{array}{l}\text { Total word count (excluding } \\
\text { summary, references and legends): }\end{array}$ & 6541 & No. of figures: & 5 \\
\hline Summary: & 219 & No. of Tables: & 4 \\
\hline Introduction: & 1190 & $\begin{array}{l}\text { No of Supporting } \\
\text { Information files: }\end{array}$ & $\begin{array}{l}\text { 8 (Fig. S1, S2; Table S1- } \\
\text { S5, Notes S1) }\end{array}$ \\
\hline Materials and methods: & 3024 & & \\
\hline Results: & 845 & & \\
\hline Discussion: & 1249 & & \\
\hline Conclusions: & 161 & & \\
\hline Acknowledgements: & 64 & & \\
\hline
\end{tabular}


23

24

\section{Aims:}

Heterogeneous canopies in temperate montane forests affect microclimate and soil characteristics, with important effects on soil microbial communities and related processes. Here, we studied the interactions between plant root traits and soil bacterial and fungal communities in closed forest and gaps in a mixed forest along an elevational gradient in the French Alps (1400, 1700 and 2000 $\mathrm{m})$.

\section{Methods:}

Samples were separated into three fractions (plant root endosphere, rhizosphere and bulk soil), to further investigate the influence of plant zones on microbial communities. Bacterial (16S) and fungal (ITS) biodiversity was determined using high throughput sequencing, along with standard measures of soil, litter and root traits.

\section{Results:}

We found that (i) microbial community diversity was higher in gaps than in closed forest because of increased root trait diversity and density; (ii) open versus closed forest patches affected phylogenetic dispersion despite differences in elevations with phylogenetic clustering in closed forest; (iii) the interaction between root traits and microbial communities was stronger for rhizosphere and endosphere compartments than for bulk soil and (iv) bacterial community composition was better explained by root traits than for fungi.

\section{Conclusions:}

Our findings highlight the importance of open gaps versus closed forest patches and associated root traits affecting microbial community structure, particularly for bacterial assemblages that exhibited a stronger interaction with root traits than for fungi.

Key words: Bacteria; closed forest; fungi; gaps; ITS; phylogenetic clustering; root traits; soil properties; 16S. 
Naturally heterogeneous canopies in forests create a mosaic of belowground responses in the activity and composition of microbial communities, that are linked primarily to the presence of specific plant species, as well as heterogeneity in microclimate and soil characteristics (Lladó et al. 2018; Muscolo et al. 2014). Disturbance in closed forests causes gaps that can alter local soil moisture, solar radiation and air and soil temperatures (de Freitas and Enright 1995; Gray et al. 2002). Understorey species then dominate in the gap, until tree growth causes the canopy to close again. Recent evidence shows that gap size alters soil microbial community structure (Muscolo et al. 2014; Yang et al. 2017a; Yang et al. 2017b) but it is not clear if these changes were primarily due to differences in the composition of plant species and/or to modifications in the local microclimate. Individual trees also structure soil microbial communities (Bach et al. 2010) through: (i) a modification in soil physicochemical parameters mostly via changes in litter quantity and quality (Baldrian 2017; Dukunde et al. 2019; Prescott and Grayston 2013; Saetre and Bååth 2000), (ii) root traits and root exudates in the rhizosphere (Colin et al. 2017; Lladó et al. 2018), in addition to (iii) the modifications in microclimatic conditions mentioned above. Here, we aim to identify whether gaps in naturally heterogeneous forests affect bacterial and fungal community structure through changes in microclimate, soil physicochemical parameters or vegetation, with a specific focus on root traits of both trees and understory species. To achieve our objective, we use an elevational gradient to observe if shifts in soil microbial diversity between gaps and closed forests are reflected in diverse climatic and soil conditions (but with minimal differences in soil texture).

Studying forest microbial diversity and structure along climate and soil gradients is challenging because factors can co-vary (McCain and Grytnes 2010). Nevertheless, elevational gradients permit the study of several abiotic factors, since major changes in these factors are found along relatively short distances (Körner 2007; Ren et al. 2018). Based on bacterial taxonomic diversity, contradicting results have been found in temperate regions, with taxonomic richness varying 
relationship (Singh et al. 2012), or not showing any relationship (Shen et al. 2014). Fungal richness has been observed to either decrease at high elevation (Bahram et al. 2012; Kernaghan and Harper 2001), or have a hump-backed shape along the gradient (Miyamoto et al. 2014). Several studies have included both fungal and bacterial communities, but trends varied (Ren et al. 2018; Shen et al. 2014; Siles and Margesin 2016). These contradicting results are possibly because different environmental variables along the elevational gradient affect community assemblages (Coince et al. 2014). Here, our approach is to examine microbial diversity in gaps and closed forest along an elevational gradient, to determine if the patterns observed in response to local differences are repeated along the elevational gradient.

Any modifications in soil microbial community assemblages will have a cascade of effects on soil structure and nutrient cycling, including: (i) soil aggregation and aggregate stability (Baumert et al. 2018; Chenu and Sotzky 2002) and (ii) decomposition processes (Kohout et al. 2018; Schneider et al. 2012). Gaps in forests might be beneficial to microbial communities through increases in their biomass and activity (Muscolo et al. (2014); Yang et al. (2017b)). If microorganisms are more abundant and active in gaps, soil aggregate stability and litter decomposition should be enhanced. However, these processes are also linked to the plant species present and their chemical and physiological traits (Grigulis et al. 2013; Poirier et al. 2018). Prescott and Grayston (2013) found that the main factors associated to differences in microbial communities in litter, forest floors and soil were $\mathrm{pH}$ and base cation content of the litter and whether the trees were broadleaf or coniferous. Besides, Brant et al. (2006) revealed that in forest ecosystems of Oregon, Pennsylvania, and Hungary, root carbon (C) inputs exerted a larger control on microbial community composition than litter inputs. Plant species diversity and root density are also greater in gaps compared to closed forests (Mao et al. 2015) due to a higher presence of shrubs, forbs and grasses, benefitting the activity of rhizosphere microbial communities (Kuzyakov and Blagodatskaya 2015). Therefore, even though a higher input of litter is expected in closed forests, the increase in root density and diversity, and associated litter, could result in more diverse and active microbial communities in gaps. 
Approaches for studying microbial diversity along gradients have changed from taxonomic to

102 phylogenetic in recent years (Parks and Beiko 2013). Phylogenetic clustering processes are observed when evolutionarily related organisms coexist due to restricting abiotic or biotic conditions. Several studies have found that phylogenetic clustering increases with elevation for bacterial communities (Bryant et al. 2008; Wang et al. 2012; Zhang et al. 2018). However, this filtering (i.e. environmental selection against certain species) is not only mediated by abiotic factors along the gradient but also by biotic interactions (Goberna et al. 2014a; Mayfield and Levine 2010) and so, there might be a role of gaps and closed forests in phylogenetic patterns. To the best of our knowledge, there is no study of the effects of gaps and closed forests in temperate forests, where changes in root diversity and density and microclimatic conditions are expected to influence strongly the bacterial phylogenetic patterns.

Ecological habitat (i.e. rhizosphere or bulk soil) is the main factor structuring bacterial communities (Uroz et al. 2010), due primarily to the supply of rhizodeposits released from live roots (Philippot et al. 2013; Shi et al. 2012). Rhizodeposits include root cells and tissues, exudates, mucilage, volatiles and soluble lysates that are sloughed-off as a root grows through soil (Uren 2000). However, recent studies have shown that the structure of fungal communities are not related to these rhizodeposits, but are strongly related to tree species (Urbanová et al. 2015; Uroz et al. 2016) mainly through litter quality that affects community composition of saprotrophic and ectomycorrhizal (ECM) fungi (Aponte et al. 2013; Prescott and Grayston 2013). If root traits differ between gaps and closed forest, modifications in bacterial communities in particular, should be observed within the rhizosphere compared to bulk soil.

Using an elevational gradient to observe if patterns of microbial diversity and structure between gaps and closed forest are repeated along the gradient, we aim at addressing four hypotheses. First, we hypothesize that microbial community diversity will be higher in gaps than in closed forest because of increased root trait diversity and density. Second, we expect to observe phylogenetic clustering in closed forest due to reduced root trait diversity and density compared to gaps. Third, we hypothesize that the interaction between root traits and microbial communities 
will be stronger for rhizosphere and endosphere compartments than for microbial communities inhabiting bulk soil. Finally, we expect that bacterial communities will be more strongly affected by ecological habitat (bulk soil, rhizosphere or endosphere) than fungal communities. These modifications to patterns in community assemblage should be repeated along the elevational gradient, because plant communities should have a greater effect on structuring microbial communities than abiotic factors, because of the habitat quality that they provide.

\section{Materials and Methods:}

Study site

Field sites are located near Chamrousse, Isère, French Alps $\left(45^{\circ} 6^{\prime} \mathrm{N}, 5^{\circ} 54^{\prime} \mathrm{E}\right)$. Three mixed, mature, naturally regenerated forests of Norway spruce (Picea abies (L.) Karst.), Silver fir (Abies alba Mill.), European beech (Fagus sylvatica L.) and Mountain pine (Pinus uncinata Ramond ex DC.) growing at elevations of 1400 (Prémol), 1700 (Bachat-Bouloud) and 2000 m a.s.l. (near Achard lake, at the treeline) were sampled to assess the effects of changes along elevation for soil physicochemical properties, microbial communities, litter and root traits. Plant species composition shifts from $1400 \mathrm{~m}$ to $2000 \mathrm{~m}$ with broad-leaved species almost absent above 1700 m. F. sylvatica is one of the dominant species at $1400 \mathrm{~m}$ and is not present at 1700 and above. A. alba, P. abies, and P. uncinata are the most dominant species at $1400 \mathrm{~m}, 1700 \mathrm{~m}$, and $2000 \mathrm{~m}$, respectively. P. abies is the only species present at all elevations (Mao et al. 2015; Wang et al. 2018b). At the three sites, the forest shows spatial heterogeneity with closed canopy forests and open canopy areas (>10 m diameter) formed through tree mortality after disturbances such as storm or tree felling. Vegetation composition in open canopy areas also changes with elevation with Gallium rotundifolium, Lysimachia nemorum and Luzula nivea being the most dominant species at $1400 \mathrm{~m}$ and Rhododendron ferrugineum and Vaccinium myrtillus at 1700 and $2000 \mathrm{~m}$ (Mao et al. 2015; Prieto et al. 2015).

As species composition changed along the elevation gradient, a sampling design comparing closed forest and gaps at each site was selected. This approach is a mean of standardization of the effect of vegetation through the comparison between closed forest and gaps along the elevational 
gradient. This patch-gap mosaic approach has been used to discern between abiotic and biotic mechanisms underlying the coexistence of phylogenetically related bacteria in a dryland environment (Goberna et al. 2014) but to our knowledge, has never been used to study microbial communities along environmental gradients. A detailed description of selected sites can be found in Wang et al. (2018a) and Mao et al. (2015) and a complete description of species and abundance of herbs and trees in closed forest and gaps at the three elevations can be found in Table S1.

The study sites possess similar soil type, and differences between the sites are mainly caused by climatic conditions and the type of vegetation. Soils are acidic at all sites, ranging from (a) "Cambisols (Hyperdystric)" according to the World Reference Base for Soil Resources (IWG 2007), above green schist and with an abundant water supply at $1400 \mathrm{~m}$, to (b) "Cambisols (Humic, Hyperdystric)", above the crystalline formation at $1700 \mathrm{~m}$, and to (c) "Epileptic Umbrisols (Hyperdystric)", above the crystalline formation at $2000 \mathrm{~m}$ (Joud 2006; Mao et al. 2012). More details on the study site are available in Mao et al. $(2013,2015)$ and Wang et al. (2018b).

The air and soil temperatures (10 cm depth) in two closed forests and two gaps were assessed in the three elevations from September $28^{\text {th }}, 2010$ to March $3^{\text {rd }}, 2014$ (Table S2, Fig. S2) with a portable thermistor thermometer (HI-93510N Hanna Instruments) in soil trenches adequately covered by insulation. Additionally, data from Wang et al. (2018a) were used to include soil water potential $(\psi)$ in the microclimate and climate assessment (Table S2). These authors used electrical resistance blocks (WaterMark, IRROMETER Company, Inc., USA) installed in one gap and one closed forest at 1400 and $1700 \mathrm{~m}$ (but not at $2000 \mathrm{~m}$ as equipment was stolen) from September $10^{\text {th }}, 2012$ to November $18^{\text {th }}, 2013$.

\section{Sampling and storage}

In each location, three different paired plots (gap versus closed forest) with representative patches of closed forests and gaps were chosen (Fig. 1). The conditions for the selection of these pairs were: (i) in closed forest, at least three adult trees of the dominant canopy species were present in 

and a diameter greater than $8 \mathrm{~m}$. In closed forests, samples were taken from between trees whilst in gaps, samples were taken in the middle of the gap in order to avoid as much as possible the influence surrounding forest. Four different surface soil samples $(0-10 \mathrm{~cm})$ were collected in each plot using sterilised material: (i) a soil cylinder for fine root analysis, (ii) a plastic bag with 10 to $20 \mathrm{~g}$ of soil for microbial analysis, (iii) a sample of leaf debris from the surface (hereafter termed 'litter') and (iv) one $0.75 \mathrm{dm}^{3}$ container of soil for measurements of aggregate stability. A total of 18 samples of each type were collected: 3 elevations x 6 samples at each site three in gaps and three in closed forests). Of each of these 18 samples collected for root analysis, 3 sample fractions were separated: root, rhizosphere and bulk soil making a total of 54 samples. Soil samples were collected during July $7^{\text {th }}-10^{\text {th }}, 2014$, at the peak of the summer season when microbial activity at the three elevations is expected to be at its maximum.

Soil samples for root, litter and microbial analysis were kept in a freezer at $-20^{\circ} \mathrm{C}$ until analyses were performed. Soil samples for aggregate stability tests were air-dried in the laboratory until they were processed approximately a month after they were collected.

Soil physicochemical properties

Soil was sieved at $2 \mathrm{~mm}$ after air drying and the soil fraction $<2 \mathrm{~mm}$ was used to assess physicochemical properties. Soil samples were sent to Natural Resource Management (Berkshire, UK). Soil pH was measured in water as 1:2.5 extract. Soil organic matter content was determined via loss-on-ignition at $500{ }^{\circ} \mathrm{C}$ (Dean 1974). Total nitrogen $(\mathrm{N})$ and carbon $(\mathrm{C})$ were determined via the DUMAS method (Shea and Watts 1939). Available potassium (K) and magnesium (Mg) were determined through ammonium nitrate extraction and available phosphorus (P) was measured via Olsen (extraction on 0.5 M sodium bicarbonate, (Olsen et al. 1954)). Soil texture was determined by laser-diffraction analysis (McCave et al. 1986). The soil sample was previously digested in hydrogen peroxide solution to destroy the organic matter and sodium hexametaphospate to release the bound clay particles. 
Aggregate stability was determined by the fast wetting standard method, ISO/CD 10930, developed by Le Bissonnais (1996). This methodology is appropriate to compare the behaviour of a large range of soils during rapid wetting mimicking heavy rainstorms in summer. Initially, 5 $\mathrm{g}$ of aggregates $(3-5 \mathrm{~mm})$ were gently immersed in $50 \mathrm{ml}$ of deionized water for $10 \mathrm{~min}$; water was then removed with a pipette and the soil material was transferred to a $50-\mu \mathrm{m}$ sieve previously immersed in ethanol. The $50 \mu \mathrm{m}$ sieve immersed in ethanol was gently moved five times to separate fragments smaller and bigger than $50 \mu \mathrm{m}$. The $>50 \mu \mathrm{m}$ fraction was collected, oven-dried and gently dry-sieved by hand on a column of six sieves: 2000, 1000, 500, 200, 100 and $50 \mu \mathrm{m}$. The mass percentage of each size fraction was calculated, and the aggregate stability was expressed by computation of the mean weight diameter (MWD).

Fine roots and litter

Soil cylinders and litter samples were defrosted. Litter samples were gently washed and rinsed with deionised water and dried at $40^{\circ} \mathrm{C}$ until constant weight. Root samples were also washed gently with deionised water and divided in two subsamples: 1) a representative subsample that was selected for scanning and later drying in the oven at $40^{\circ} \mathrm{C}(\mathrm{n}=18)$ and the 2$)$ remaining root material of the sample that was dried at $40^{\circ} \mathrm{C}$ until constant weight $(\mathrm{n}=18)$. Both subsamples were weighed after drying.

Roots selected for morphological measurement were stained with methylene blue $\left(1 \mathrm{~g} \mathrm{~L}^{-1}\right)$ to increase the contrast and allow the detection of fine roots. Then, roots were placed in a tray with deionised water and scanned (Epson@ $\odot$ V700 perfection) at a resolution of 1200 dpi. Analysed roots were then recovered, and oven dried at $40{ }^{\circ} \mathrm{C}$ and weighed to obtain dry mass. Root images were analysed with the WinRhizo® software (Pro version 2007, Regent Instrument, Quebec, Canada) using the automatic thresholding option and Lagarde's mode with a filter identifying roots when length was five times the width. Total root length and the length of roots in seven diameter classes (width $0 \mathrm{~mm}$ to $1 \mathrm{~mm}$ in $0.2 \mathrm{~mm}$ classes and $1 \mathrm{~mm}$ to $2 \mathrm{~mm}$ in $0.5 \mathrm{~mm}$ classes) were measured with the software. Specific root length (SRL) was calculated as the ratio between 
total root length and root dry mass. The percentages of very fine (VFR, diameter $<0.2 \mathrm{~mm}$ ) and

234 fine (FR, $0.2<$ diameter $<1 \mathrm{~mm}$ ) roots were defined as the ratio of length in the concerned root classes to total root length (Miller and Jastrow 1990). Total root mass density (RMD) was calculated by the ratio of total root dry mass and the soil volume extracted. Total root length density (RLD) was calculated by the ratio of total root length and the soil volume extracted. Total root dry mass was calculated as the sum of the dry mass of roots selected for morphological analysis and those of the remaining roots. Root dry matter content (RDMC) was calculated as the ratio of the root dry weight and root fresh weight.

241 The concentrations of water soluble compounds (cellulose and lignin; $\mathrm{mg} \mathrm{g}^{-1}$ ) in root and litter samples $(\mathrm{n}=18$ for litter and $\mathrm{n}=6$ for roots as replicates were combined due to limited sample amount), were obtained by the Van Soest Method (1963) with a Fibersac fibre analyser (Ankom, Macedon, USA). Root and litter $\mathrm{C}$ and $\mathrm{N}$ concentrations $(\mathrm{n}=18$ for each) were measured using an elemental analyser (Thermo-Finnigan EA1112, Milan, Italy).

Soil microbial communities

The protocol for cleaning roots and obtaining root, rhizosphere and bulk soil samples was performed following Bulgarelli et al. (2012, 2015). Briefly, loose soil was manually removed from the root system and stored as the bulk soil sample. Roots were collected in $50 \mathrm{ml}$ falcon tubes containing $10 \mathrm{ml}$ PBS-S buffer $\left(130 \mathrm{mM} \mathrm{NaCl}, 7 \mathrm{mM} \mathrm{Na}_{2} \mathrm{HPO}_{4}, 3 \mathrm{mM} \mathrm{NaH}_{2} \mathrm{PO}_{4}, \mathrm{pH} 7.0\right.$, $0.02 \%$ Silwet L-77) and washed for 20 minutes at $180 \mathrm{rev} \mathrm{min}^{-1}$ on a shaking platform. These roots were transferred to a new falcon tube and subjected to a second washing treatment $(20$ minutes at $180 \mathrm{rpm}$ in $3 \mathrm{ml}$ PBS-S buffer). The soil suspensions collected in the falcon tubes after the first and second washing treatments were combined, centrifuged at 4000g for $20 \mathrm{~min}$ and the pellet, considered as the rhizosphere sample, was frozen and stored at $-20^{\circ} \mathrm{C}$ until further processing. Double-washed roots were then transferred to a new falcon tube with $3 \mathrm{ml}$ PBS and sonicated for 2 minutes at $160 \mathrm{~W}$ to enrich for microbes living in close association with root tissues. Roots were removed from PBS-S, rinsed in a fresh volume of $10 \mathrm{ml}$ PBS-S buffer and 
ground with a mortar and pestle in liquid nitrogen. Pulverised roots (considered as the 'root' sample) were collected in $15 \mathrm{ml}$ falcon tubes and stored at $-20^{\circ} \mathrm{C}$ until further processing.

Total DNA was extracted from soil $(0.25 \mathrm{~g})$ and the rhizosphere and root fractions $(0.25 \mathrm{~g}$ when possible and the entire material available when quantity was less than $0.25 \mathrm{~g}$ ). DNA extraction was performed using PowerSoil®-htp96 Well Soil DNA Isolation Kit according to manufacturer's instructions (MOBIO Laboratories, UK).

Bacterial and fungal community biodiversity was assessed using Illumina amplicon sequencing of 16S rRNA genes (bacteria) and the Internal transcribed spacer (ITS) region (fungi) to phylogenetically identify responsive taxa. A phylogenetic analysis was also performed for bacterial communities. Amplicon libraries were constructed according to the dual indexing strategy of Kozich et al. (2013), with each primer consisting of the appropriate Illumina adapter, an 8-nt index sequence, a 10-nt pad sequence, a 2-nt linker and the gene specific primer. For 16S, the V3-V4 hypervariable regions of the 16S rRNA gene was targeted using primers based upon the universal primer sequence $341 \mathrm{~F}$ and 806R. For ITS, region 2 (ITS2) was amplified utilising the fITS7 (forward) and ITS4 (reverse) primer sequences described in Ihrmark et al. (2012). Additional methodological details of Illumina sequencing are described in Notes S1.

Sequenced 16S rRNA paired-end reads were joined using PEAR (Zhang et al. 2014), quality filtered using FASTX tools (hannonlab.cshl.edu), length filtered with the minimum length of 300bps, presence of PhiX and adapters were checked and removed with BBTools (jgi.doe.gov/data-and-tools/bbtools/), and chimeras were identified and removed with VSEARCH_UCHIME_REF (Rognes et al. 2016) using Greengenes Release 13_5 (at 97\%) (DeSantis et al. 2006b). Singletons were removed and the resulting sequences were clustered into operational taxonomic units (OTUs) with VSEARCH_CLUSTER (Rognes et al. 2016) at 97\% sequence identity (Tindall et al. 2010). Representative sequences for each OTU were taxonomically assigned by RDP Classifier with the bootstrap threshold of 0.8 or greater (Wang et al. 2007) using the Greengenes Release 13_5 (full) (DeSantis et al. 2006b) as the reference. 
Unless stated otherwise, default parameters were used for the steps listed. ITS2 sequences were processed using the PIPITS pipeline (Gweon et al. 2015), where OTUs were taxonomically assigned against the UNITE database (Release 31.01.2016, Koljalg et al. (2013).

A four-step statistical procedure was performed to determine the interrelationships between the different variables under study: (i) examine the variations on environmental variables (soil properties and root and litter traits) in closed forest versus gaps along the elevational gradient; (ii) non-metric multi-dimensional scaling (NMDS) data ordinations of microbial data and test of the effect of closed forest versus gaps and sample fraction (root, rhizosphere and bulk soil) on their structure (Permutational Multivariate Analysis of Variance, PERMANOVA) along the elevational gradient; (iii) study of correlation between microbial community structure and environmental variables (Spearman correlations and distance-based redundancy analysis, dbRDA); and (iv) study of taxonomic and phylogenetic diversity and divergence among closed forest and gaps along the elevation for the three sample fractions (bulk soil, rhizosphere and root).

Air and soil temperatures, soil physicochemical properties and root traits were analysed by Analysis of Covariance (ANCOVA) and Student's t-tests for closed forests versus gaps (hereafter termed "tree-gap"). The tree-gap explanatory variable was treated as a factor and elevation was included as a covariate. All variables tested fulfilled ANCOVA assumptions except for SRL that was transformed and RLD, soil P, litter hemicellulose $\mathrm{N}, \mathrm{C}$, and $\mathrm{C}: \mathrm{N}$ that were analysed by Kruskal Wallis tests and Wilcoxon Rank Sum Tests. Soil water potential data were analysed with Friedman rank sum tests and post hoc comparisons were performed using Nemenyi multiple tests. Curtis dissimilarity for bacterial and fungal OTUs matrices. To indicate similarities between treatments on the NMDS configuration, the points on the NMDS ordination were overlapped with polygons and spider diagrams indicating elevation, tree-gap and soil fraction. PERMANOVA tests (adonis R function) were performed for the bacteria and fungi OTUs matrices as the response 
and the three different factors (tree-gap and soil fraction) as the explanatory variables and elevation as a covariate.

313 The relationships between the microbial community composition and the soil physicochemical variables, root and litter traits were tested using Spearman correlations between these variables and alpha (Shannon diversity index) and beta diversities (NMDS first and second axis) and a dbRDA. In order to select the environmental parameters to be included in the constrained ordination, an initial db-RDA including all parameters was performed followed by a stepwise model selection using Generalized Akaike Information Criterion (AIC, ordistep function with a backward direction). Finally, the db-RDA analysis was performed only for the variables obtained. ANOVA tests were performed on the final constrained ordination to confirm that the first two axes and the environmental variables and the final constrained ordination were significant.

Additionally, the dbRDA analyses were computed for each of the sample fractions and each of the three environmental matrices (soil, root and litter traits) to study the variance explained by these environmental variables and the bacterial and fungal composition.

Apart from the traditional taxonomic approach, a phylogenetic approach was also used as it is a useful method to measure biodiversity incorporating phylogenetic difference between species (Webb 2000). The phylogenetic approach relies on homologous genes (genes that are derived from a common ancestor). Here, we sequenced the ITS2 region for fungi which is not a homologous gene, and 16S rRNA gene for bacterial communities (which is homologous). Therefore, the phylogenetic approach was only used for bacterial communities. A phylogenetic tree was constructed based on 16S rRNA representative sequences. The sequences were aligned with PyNAST (Caporaso et al. 2010) to the Greengenes reference database (DeSantis et al. 2006a). FastTree (Price et al. 2010) was then used on the resulting alignment to produce a maximum-likelihood phylogenetic tree by iterative rearrangement of branches with generalized time-reversible (GTR) models of nucleotide evolution. This phylogenetic tree was used to generate the distance matrices and obtain two main indexes: one to measure phylogenetic 
337 diversity (Faith's Phylogenetic Diversity (Faith (1992), hereafter PD) and a second one to 338 measure phylogenetic divergence, the standardized mean nearest taxon distance (hereafter 339 ses.MNTD). Faith's Phylogenetic Diversity is a measure of the total phylogenetic branch length 340 that joins the basal node to the tips of all species in the sample. Mean nearest taxon distance 341 (MNTD) is an estimate of the mean phylogenetic relatedness between each OTU in a bacterial community and its nearest relative. The standardized mean nearest taxon distance (ses.MNTD) can be used to test for phylogenetic clustering or over dispersion as it is an index that compensates for random processes in the observed phylogenetic community structure. The standardized effects of MNTD were obtained comparing the observed phylogenetic relatedness to the pattern obtained by community randomizations holding community species richness constant (runs $=999$, iterations $=1000)$. Finally, Analysis of Covariance $($ ANCOVA) tests were performed for these indexes as response variables, tree-gap and sample fraction as explanatory variables and elevation as a covariate. The variables H, PD and ses.MNTD were transformed with a Johnson, inverse and Tukey's Ladder of Powers transformations to meet ANCOVA assumptions.

All analyses were performed in RStudio Version 1.0.136 (RStudio Team 2016) using the vegan (Oksanen et al. 2016), picante (Kembel et al. 2010), and ade4 (Dray and Dufour 2007) packages.

\section{Results}

Relationships between environmental variables and bacterial and fungal communities.

The results of the relationships between soil physicochemical properties, root and litter traits (Tables S3 and S4, Figure 2) and microbial community composition are shown in the db-RDA (Figure 3) and Spearman correlations with alpha and beta diversities (Table 2). The final db-RDA analysis (Figure 3) shows only the environmental parameters that were selected through stepwise model selection. ANCOVA tests performed on the final constrained ordination confirmed that the first two axes, the environmental variables and the final constrained ordination were significant. Bacterial alpha diversity was positively correlated with SRL and negatively correlated with RDMC and root N (Table 2). Additionally, bacterial beta diversity was positively correlated with 
soil C:N, MRD and root C and negatively correlated to SRL, VFR, RLD and litter hemicellulose. There was a clear separation between closed forests and gaps for bacteria (Figure 3), with aggregates from closed forests having greater stability (MWD), higher root dry matter content (RDMC), soil C and C:N. Gaps were associated to higher VFR and SRL.

No correlations were found between any of the parameters measured and the alpha diversity of fungi. Nevertheless, numerous soil properties (sand, SOC, N, C, C:N) and root traits (MRD, N, C and cellulose) were positively correlated with fungal beta diversity whilst other traits were negatively correlated with fungal beta diversity (clay, SRL, VFR, RLD and litter hemicellulose). As for bacterial communities, the composition of fungal communities was different between closed forests and gaps particularly for elevations 1700 and 2000 but not for $1400 \mathrm{~m}$ (Figure 3). For fungi, the environmental variables showed similar trends than those obtained for bacteria although more factors were significant (higher MRD, root $\mathrm{C}$, soil $\mathrm{N}$ and litter lignin for closed forests and higher RLD, RMD, litter C, N and hemicellulose content for gaps).

Data on the climate along the elevation (Table S2, Figure S2) showed that elevation decreased air and soil temperatures and water potential in gaps and closed forests with a gradual decrease of soil and air temperatures for closed forests and a greater decrease between 1700 and $2000 \mathrm{~m}$ for gaps. Soil and air temperatures in gaps were higher than in closed forest at the mid elevation (1700 m) but not at the lowest and highest elevations (1400 and $2000 \mathrm{~m}$ ).

The dbRDA analyses computed for the sample fractions and environmental matrices (soil, root and litter traits) showed that the variance of bulk soil communities (bacterial and fungal) was mainly explained by soil properties but not by root or litter traits (adjusted $R^{2}=0.34$ and 0.13 respectively, Table 1). Notably, the variance of rhizosphere and root bacterial communities explained by root traits was significant (adjusted $R^{2}=0.28$ and 0.23 respectively) compared to fungal communities with no significant relationships $(\mathrm{p}>0.05)$. Only soil properties significantly explained the variance of soil and rhizosphere fungal communities, with lower explained variance than in bacterial communities (Table 1). 
Effects of closed forests-gaps and elevation gradient on the structure of bacterial and fungal communities.

NMDS ordinations showed that bacterial communities were markedly distinct between closed forests and gaps along the elevation gradient (Figure 4). Conversely, fungal communities did not show this robust distinction between closed forests and gaps, but the elevational effect was evident. These findings were supported by the PERMANOVA performed for the bacterial and fungal species matrices, which showed that the main factors structuring bacterial communities were tree-gap $\left(\mathrm{R}^{2}=0.122 ; \mathrm{p}=0.001\right.$; Table 3$)$ and sample fraction $\left(\mathrm{R}^{2}=0.137 ; \mathrm{p}=0.001\right)$, and the main factors structuring fungal communities were elevation $\left(R^{2}=0.085 ; p=0.001\right)$ and treegap $\left(R^{2}=0.062 ; p=0.001\right)$. Remarkably, sample fraction did not significantly structured fungal communities $(\mathrm{p}=0.163)$.

Bacterial and fungal composition, diversity and divergence among closed forests and gaps.

401

402

403

404

405

406

407

408

409

410

411

Most sequences found in the $16 \mathrm{~S}$ dataset were members of the phyla Proteobacteria, Acidobacteria, Actinobacteria and Verrucumicrobia (Fig. S1). Within the Proteobacteria, Alphaprotebacteria was highly abundant in the three fractions. For fungal communities (ITS region), the sequences most predominant were the Basidiomycota and Ascomycota (Fig. S1). Agaricomycetes was particularly dominant across the three soil fractions and showed a slightly higher presence in bulk soil when compared to rhizosphere and root fractions.

Tree-gap $(\mathrm{p}=0.003)$ and elevation $(\mathrm{p}<0.001)$ significantly modified taxonomic diversity (Shannon's diversity index, H) for bacterial communities but not for fungal communities (Table 4, Figure 5). Namely, bacterial $\mathrm{H}$ was higher in gaps than in closed forests, and $\mathrm{H}$ in soil and rhizosphere communities noticeably increased from 1700 to $2000 \mathrm{~m}$ while $\mathrm{H}$ in root communities increased from 1400 to $1700 \mathrm{~m}$. Tree-gap $(\mathrm{p}<0.001)$ and elevation $(\mathrm{p}=0.033)$ significantly modified bacterial Phylogenetic diversity (PD) for bacterial communities. More specifically, a lower PD was found in closed forest ( $\mathrm{p}<0.001$; Figure 5). Regarding phylogenetic divergence, bacterial communities showed negative values indicating phylogenetic clustering (Figure 5) in all 
415 situations. Tree-gap modified significantly ses.MNTD ( $p=0.030$; Table 4$)$ with a particularly

416 evident effect of closed forests in reducing the bacterial ses.MNTD in rhizosphere and root

417 communities and at higher elevations.

\section{Discussion}

419 Our results highlight the importance of plant root traits for the structure and diversity of bacterial communities since bacterial community composition was better explained by root traits than for fungi. The significance of canopy heterogeneity (i.e. open versus closed forest patches) on root traits was demonstrated, along with the structuring impact on associated microbial communities.

We hypothesized that microbial community diversity would be higher in gaps than in closed forest due to increased root trait diversity and root density in gaps. These differences in root properties between closed forest and gaps were supported by our results that showed higher SRL and RLD in gaps. The closed forest and gaps influenced significantly both bacterial and fungal community structure and diversity (Table 1, Figures 3, 4). In agreement with our hypothesis, a general increase in bacterial taxonomic diversity was observed in gaps (Table 4) with a marked effect in the endosphere fraction (Figure 5). Besides the effect of root traits on microbial diversity, an increase in soil temperature in gaps is generally positively related to an increase in soil microbial activities (Muscolo et al. 2007). Here, we found that soil temperature in gaps at a depth of $10 \mathrm{~cm}$ at $1700 \mathrm{~m}$ was higher (mean temperature of $5.27^{\circ} \mathrm{C}$ in closed forest and $6.68^{\circ} \mathrm{C}$ in gaps), which could also partially explain the observed increase in taxonomic diversity in gaps. Since microbial communities and roots are major biotic contributors to soil aggregation (Lehmann et al. 2017), we expected a higher soil aggregate stability in gaps. Contrary to our expectations, soil in closed forests had a higher aggregate stability. Thus, our results highlight the importance of other factors for aggregate stability, such as RDMC, soil $\mathrm{C}$ and $\mathrm{C}: \mathrm{N}$ ratio that were significantly higher in closed forest and are important contributors to soil aggregate stability (Gale et al. 2000; Tisdall and Oades 1982). 
440 Although we found significant effects of closed forest and gaps on the structure of fungal

441 communities along the elevational gradient (Figure 2, Table 1), the effect on fungal taxonomic 442 diversity was not significant (Table 4). These results are in line with results from Collins et al. 443 (2018), who found a high spatial variation of fungal diversity and abundance compromising the 444 predictive power of vegetation and soil properties. This non-significant effect of closed forest and gaps along the elevational gradient on fungal taxonomic diversity could be related to (i) plantmicrobe interactions and their specificity (Brundrett 2002; Uroz et al. 2016),(ii) the capacity of dispersion of fungi that could make them very variable across all situations and (iii) the complexities of the Fungi kingdom, as it is an extensive category and successional changes in communities could be masked when using diversity indices. Additionally, we acknowledge that we did not distinguish the presence of saprotrophic, ectomycorrhizal and arbuscular mycorrhizal fungi, which could explain the lack of trends observed for fungal communities.

We observed a phylogenetic clustering in all situations for bacterial communities (negative ses.MNTD values, Figure 5). This observed clustering for bacteria agrees with current consensus as previous studies showed that bacterial communities tend to contain lower taxonomic diversity and are more likely to be phylogenetically clustered than expected by chance (Bryant et al. 2008; Horner-Devine and Bohannan 2006). Consistent with our second hypothesis, we found a lower ses.MNTD in closed forest compared to gaps. This finding indicates the existence of phylogenetic clustering in these environments and suggests the presence of environmental conditions that may cause clustering in closed forest compared to gaps. However, we did not observe this lower ses.MNTD in closed forest compared to gaps at $1400 \mathrm{~m}$, which could be related to the dominance of broadleaved species at this elevation (Prescott and Grayston 2013). Similar results were found by Goberna et al. (2014b) in drylands when comparing vegetation patches to bare soil. These authors found that bacterial communities in gaps were phylogenetically clustered compared to vegetation patches. Goberna et al. (2014) suggested that traits related to environmental stress tolerance are conserved under resource limited conditions (gaps in drylands), while under environments with a high availability of resources (vegetation patches) competitive exclusion of 
467 poorly competitive clades becomes significant (Mayfield and Levine 2010). Consequently, these

468 findings agree with our results if we consider that in this study, resource limited conditions could

469 be found in closed forest compared to gaps since vegetation in gaps had thinner roots with lower

470 RDMC and greater SRL, and higher litter C, N and hemicellulose. Elevation altered the effect of

471 patches on the divergence of bacterial communities, that is likely due to the increase in dominant

472 coniferous species in closed forest and the difference in microclimatic conditions at lower

473 elevations. We found an increase of soil $\mathrm{C}$ in closed forest at higher elevations related to the lower

474 decomposability of coniferous litter (Jonard et al. 2017). However, we did not observe the

475 expected decrease in $\mathrm{N}$ and acidification of the soil (Hornung 1985).

476 With the three-stratum sampling approach (soil, rhizosphere and root), we have shown the key

477 role of root properties on microbial communities from bulk soil to root endosphere. We have also highlighted the strength of this sampling approach to adequately identify processes or environmental variables affecting community assemblage. We hypothesized that microbial communities from root and rhizosphere would be greatly affected by root traits compared to microbial communities in the soil. The dbRDA analyses (Table 2) demonstrated a strong relationship between root traits and microbial communities for bacteria, showing that the variance of rhizosphere and root bacterial communities was significantly explained by root traits. A study on root traits along a boreal-temperate forest gradient also demonstrated strong relationships between absorptive root morphology and fungal and bacterial communities with better correlations in rhizosphere samples than in bulk soils (Ostonen et al. 2017). Thus, according to our last hypothesis, the influence of root traits in the rhizosphere and endosphere on bacterial communities was higher than for fungal communities. These results were confirmed with Spearman correlations showing that bacterial Shannon diversity was affected by root traits (SRL, RDMC and N content), but this was not the case for fungi. Similar results in elevational gradients were obtained by Ren et al. (2018) who found that plant diversity modified bacterial but not fungal diversities, as was previously suggested by several authors (Shen et al. 2014; Siles and Margesin 2016) indicating that fungi respond to multiple variables (Jarvis et al. 2015; Ren et al. 2018). This 
strong association between root traits and bacterial communities, but not for fungal communities, could be related to the limited capacity of dispersion of bacterial communities as compared to fungal communities with their hyphal growth and branching. According to this, we found that several soil properties were correlated with the beta diversity of fungal communities but not for bacterial communities. Besides, we found that root traits were correlated with both bacterial and fungal beta diversities, mainly SRL, VFR, MRD, RLD and C content, highlighting the importance of fine absorptive roots and root $\mathrm{C}$ for microbial communities (Bardgett et al. 2014; de Graaff et al. 2010; Liu et al. 2018).

We found a remarkably high variance of both bacterial and fungal communities explained by soil properties in the dbRDA analysis. This result is in agreement with the proposed hierarchy concerning the contribution of soil and plant species on microbial communities' structure and composition (Bulgarelli et al. 2012; Lareen et al. 2016; Philippot et al. 2013). In other words, soil physicochemical properties determine the composition of the soil microbiome, whereas root traits and exudates can gradually alter the soil microbiome (Bever et al. (2012); van der Putten et al. (2013).

\section{Conclusions}

We found that bacterial community composition was better explained by root traits than for fungi. As expected, this interaction between microbial communities and root traits was more intense in communities isolated from rhizosphere and roots than for the bulk soil. In addition, we found that canopy heterogeneity (i.e. closed forest versus gaps) along the elevation gradient structured bacterial and fungal communities and modified bacterial phylogenetic diversity that decreased in closed forest. Finally, we found that bacterial phylogenetic dispersion was higher in gaps along the elevation gradient. Our results highlight the importance of incorporating (i) root traits, (ii) canopy forest heterogeneity (closed forest versus gaps in this case), and (iii) soil-rhizosphereendosphere sample fractions in studies along environmental gradients for the correct understanding of factors affecting microbial community assemblage. Overall, our findings 
520 highlight the importance of soil properties for bulk soil and rhizosphere microbial communities

521 and the importance of root traits for rhizosphere and root endosphere bacterial communities but 522 not for fungal communities. 
524 LMM was funded with a Marie Curie IEF fellowship (FP7 European program, ref. 626666/2013).

525 Funding for CFB was provided by the French and Mexican governments (ECOPICS project, 526 ANR-16-CE03-0009 and CONACYT-273659). Many thanks to Hervé Rey (CIRAD, France),

527 Francois Pailler (INRA France) and Patricia Tabernero for their help with field and laboratory 528 work. Thanks are due to the Mairie de Chamrousse for access to fieldsites.

\section{Author Contribution}

LMM, RIG, AS, YLB designed, carried out the experimental research and analysed the data. HSG, CFB, AO carried out the experimental research and analysed the data. LMM, RIG, AS wrote the manuscript. All authors edited the manuscript.

Supporting Information

534

Fig. S1. Phylum and class of bacterial and fungal communities along the elevation and in gaps and closed forest.

Fig. S2. Soil temperature data in gaps and closed forest, over time and for the three elevations.

Table S1 Dominant species and abundance of herbs and trees in gaps and closed forest along the elevation gradient.

Table S2 Climate and microclimate data along the elevation gradient in gaps and closed forest.

Table S3 Soil physicochemical properties along the elevation gradient in gaps and closed forest.

Table S4 Root and litter traits along the elevation gradient in gaps and closed forest.

Table S5. Abbreviations used in this paper and the ITS region. 


\section{Tables:}

Table 1. Partition of variance in constrained ordination distance-based Redundancy Analysis (dbRDA) for the three sample fractions and the three set of environmental variables (soil properties, root and litter traits). The degrees of freedom (Df), proportion of the variance explained by each model $\left(\mathrm{R}^{2}\right)$, adjusted $\mathrm{R}^{2}$ (Adj. $\left.\mathrm{R} 2\right)$ and its significance $(* \mathrm{P}<0.05$, ** $\mathrm{P}<0.01$, $* * * \mathrm{P}<0.001, \mathrm{~ns}=$ not significant $)$ are shown.

\begin{tabular}{|c|c|c|c|c|c|c|c|c|c|c|c|c|c|}
\hline \multicolumn{2}{|c|}{ Fraction } & \multicolumn{4}{|c|}{ Bulk soil } & \multicolumn{4}{|c|}{ Rhizosphere } & \multicolumn{4}{|c|}{ Root } \\
\hline & & Df & $\mathbf{R}^{2}$ & Adj. $R^{2}$ & & Df & $\mathbf{R}^{2}$ & Adj. $R^{2}$ & & Df & $\mathbf{R}^{2}$ & Adj. $R^{2}$ & \\
\hline Soil properties & & 11 & 0.79 & 0.34 & $\star *$ & 11 & 0.81 & 0.39 & ** & 11 & 0.76 & 0.24 & * \\
\hline Root traits & Bacteria & 10 & 0.66 & 0.10 & ns & 10 & 0.73 & 0.28 & * & 10 & 0.71 & 0.23 & * \\
\hline Litter traits & & 6 & 0.40 & 0.04 & ns & 6 & 0.45 & 0.12 & ns & 6 & 0.39 & 0.02 & $\mathrm{~ns}$ \\
\hline Soil properties & & 11 & 0.73 & 0.13 & * & 11 & 0.70 & 0.15 & $\star * *$ & 11 & 0.80 & 0.07 & ns \\
\hline Root traits & Fungi & 10 & 0.65 & 0.06 & ns & 10 & 0.61 & 0.06 & ns & 10 & 0.71 & 0.00 & ns \\
\hline Litter traits & & 6 & 0.39 & 0.02 & $\mathrm{~ns}$ & 6 & 0.36 & 0.02 & ns & 6 & 0.47 & 0.07 & * \\
\hline
\end{tabular}


Table 2. Spearman's correlation coefficients between bacterial and fungal alpha diversity (H:

Shannon index) and beta diversity (NMDS1 and NMDS2), and soil properties, root and litter traits $(* * * * \mathrm{P}<0.0001, * * * \mathrm{P}<0.001, * * \mathrm{P}<0.01, * \mathrm{P}<0.05)$. Refer to Table S5 for abbreviations.

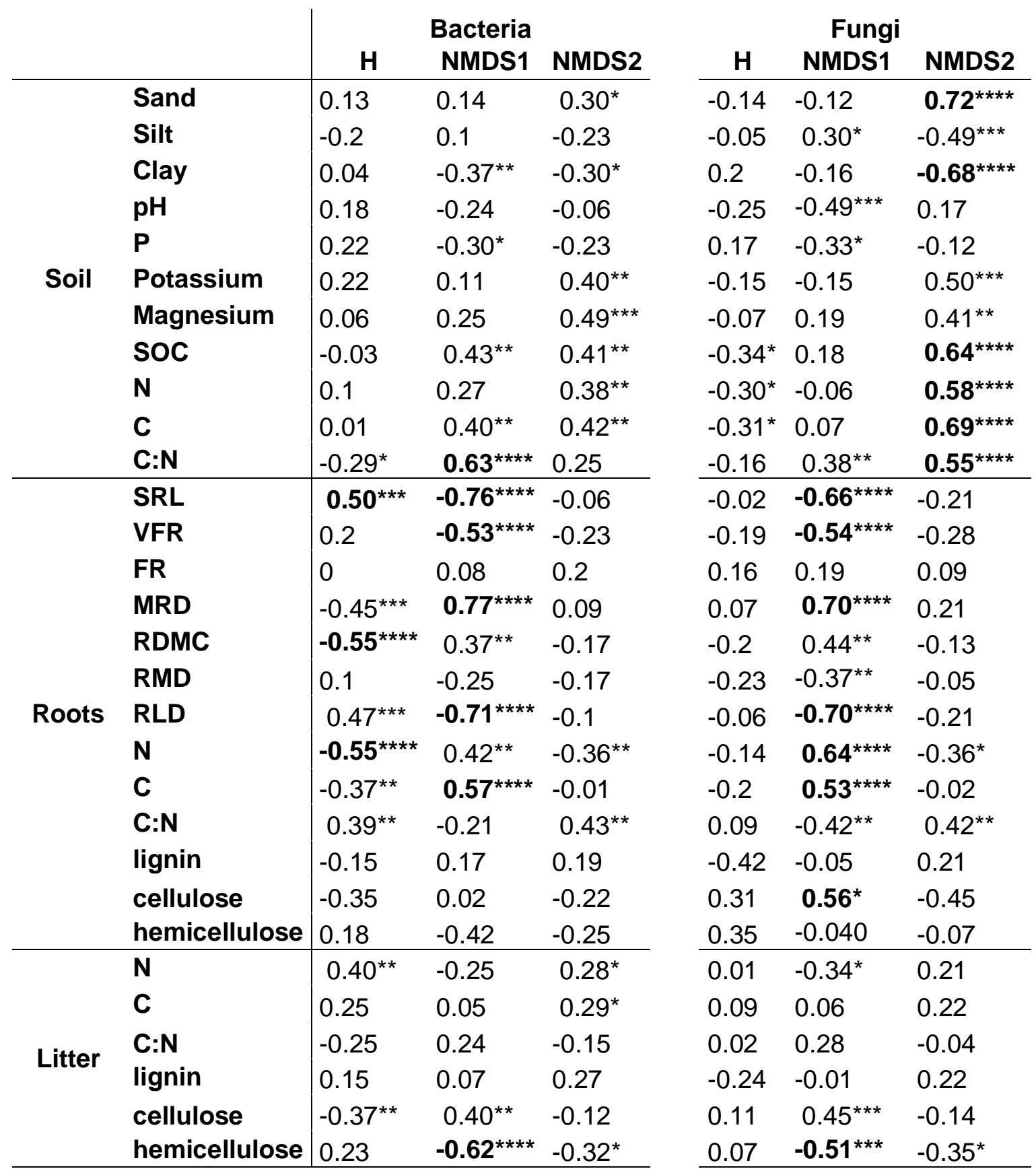


Table 3. Effects of tree-gap, elevation and sample fraction and their interactions on the structure of bacterial and fungal communities assessed with PERMANOVA. The degrees of freedom (Df),), sum of squares (sum of sqs), mean of squares (mean of sqs), the F. statistic, the proportion of the variance explained by each model $\left(\mathrm{R}^{2}\right)$ and probability $(\mathrm{P})$ are shown.

\begin{tabular}{|c|c|c|c|c|c|c|c|c|c|c|c|c|}
\hline \multirow[b]{2}{*}{ Factors } & \multicolumn{6}{|c|}{ Bacteria } & \multicolumn{6}{|c|}{ Fungi } \\
\hline & Df & $\begin{array}{l}\text { Sum } \\
\text { of sqs }\end{array}$ & $\begin{array}{l}\text { Mean } \\
\text { of sqs }\end{array}$ & $\mathbf{F}$ & $\mathbf{R}^{2}$ & $P(>F)$ & Df & $\begin{array}{l}\text { Sum of } \\
\text { sqs }\end{array}$ & $\begin{array}{l}\text { Mean } \\
\text { of sqs }\end{array}$ & $\mathbf{F}$ & $\mathbf{R}^{2}$ & $P(>F)$ \\
\hline Tree-gap & 1 & 1.0542 & 1.05417 & 8.7707 & 0.122 & 0.001 & 1 & 1.2443 & 1.24429 & 3.3684 & 0.062 & 0.001 \\
\hline Elevation & 1 & 0.5703 & 0.57034 & 4.7452 & 0.066 & 0.001 & 1 & 1.7022 & 1.70222 & 4.608 & 0.085 & 0.001 \\
\hline Samplefraction & 2 & 1.1862 & 0.59308 & 4.9344 & 0.137 & 0.001 & 2 & 0.8555 & 0.42776 & 1.158 & 0.043 & 0.163 \\
\hline Elevation:Tree-gap & 1 & 0.3944 & 0.3944 & 3.2814 & 0.045 & 0.003 & 1 & 0.9148 & 0.91483 & 2.4765 & 0.046 & 0.001 \\
\hline Elevation:Samplefraction & 2 & 0.2742 & 0.13708 & 1.1405 & 0.032 & 0.249 & 2 & 0.4946 & 0.24729 & 0.6694 & 0.025 & 0.994 \\
\hline Tree-gap:Samplefraction & 2 & 0.2578 & 0.12892 & 1.0726 & 0.030 & 0.34 & 2 & 0.4086 & 0.2043 & 0.553 & 0.020 & 1 \\
\hline $\begin{array}{l}\text { Elevation:Tree- } \\
\text { gap:Samplefraction }\end{array}$ & 2 & 0.2495 & 0.12474 & 1.0378 & 0.029 & 0.366 & 2 & 0.4484 & 0.22419 & 0.6069 & 0.022 & 0.998 \\
\hline Residuals & 39 & 4.6875 & 0.12019 & & 0.540 & & 38 & 14.0373 & 0.3694 & & 0.698 & \\
\hline Total & 50 & 8.6741 & & & 1 & & 49 & 20.1057 & & & 1 & \\
\hline
\end{tabular}


Table 4. Analysis of covariance (ANCOVA) table showing the effects of tree-gap, elevation and sample fraction on bacterial and fungal taxonomic $(\mathrm{H})$ and phylogenetic (PD) diversities and phylogenetic divergence (ses.MNTD). The degrees of freedom (Df), the F statistic and P values are shown. Refer to Table S5 for abbreviations.

\begin{tabular}{|c|c|c|c|c|c|c|}
\hline & & \multirow[b]{2}{*}{ Df } & \multicolumn{2}{|c|}{ Bacteria } & \multicolumn{2}{|c|}{ Fungi } \\
\hline & & & $\mathbf{F}$ & $P$ value & $\mathbf{F}$ & $P$ value \\
\hline \multirow{7}{*}{$\mathbf{H}$} & Tree-gap & 1 & 10.25 & 0.003 & 0.048 & 0.829 \\
\hline & Elevation & 1 & 14.89 & $<0.001$ & 0.02 & 0.889 \\
\hline & Samplefraction & 2 & 0.52 & 0.599 & 3.231 & 0.051 \\
\hline & Elevation:Tree-gap & 1 & 0.432 & 0.515 & 2.102 & 0.155 \\
\hline & Elevation:Samplefraction & 2 & 0.142 & 0.868 & 0.48 & 0.622 \\
\hline & Tree:Samplefraction & 2 & 1.099 & 0.343 & 1.524 & 0.231 \\
\hline & $\begin{array}{l}\text { Elevation:Tree- } \\
\text { gap:Samplefraction }\end{array}$ & 2 & 0.559 & 0.576 & 0.049 & 0.952 \\
\hline \multirow{7}{*}{ PD } & Tree-gap & 1 & 20.7 & $<0.001$ & & \\
\hline & Elevation & 1 & 4.879 & 0.033 & & \\
\hline & Samplefraction & 2 & 0.479 & 0.623 & & \\
\hline & Elevation:Tree-gap & 1 & 0.141 & 0.710 & & \\
\hline & Elevation:Samplefraction & 2 & 0.257 & 0.775 & & \\
\hline & Tree:Samplefraction & 2 & 1.075 & 0.351 & & \\
\hline & $\begin{array}{l}\text { Elevation:Tree- } \\
\text { gap:Samplefraction }\end{array}$ & 2 & 0.55 & 0.582 & & \\
\hline \multirow{7}{*}{ ses.MNTD } & Tree-gap & 1 & 5.106 & 0.030 & & \\
\hline & Elevation & 1 & 1.864 & 0.180 & & \\
\hline & Samplefraction & 2 & 3.117 & 0.056 & & \\
\hline & Elevation:Tree-gap & 1 & 1.681 & 0.202 & & \\
\hline & Elevation:Samplefraction & 2 & 0.506 & 0.607 & & \\
\hline & Tree:Samplefraction & 2 & 1.237 & 0.301 & & \\
\hline & $\begin{array}{l}\text { Elevation:Tree- } \\
\text { gap:Samplefraction }\end{array}$ & 2 & 0.033 & 0.968 & & \\
\hline
\end{tabular}


a)

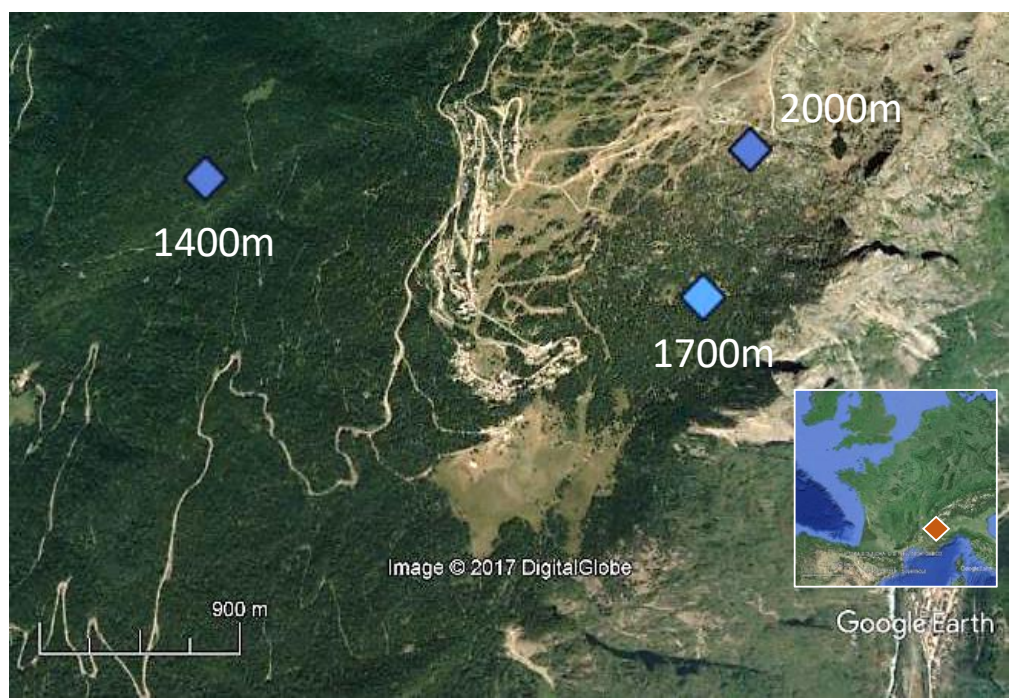

b)

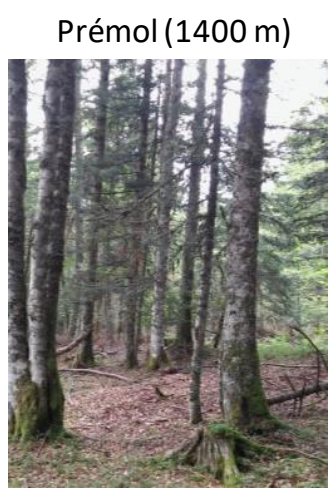

Bachat Bouloud (1700m)
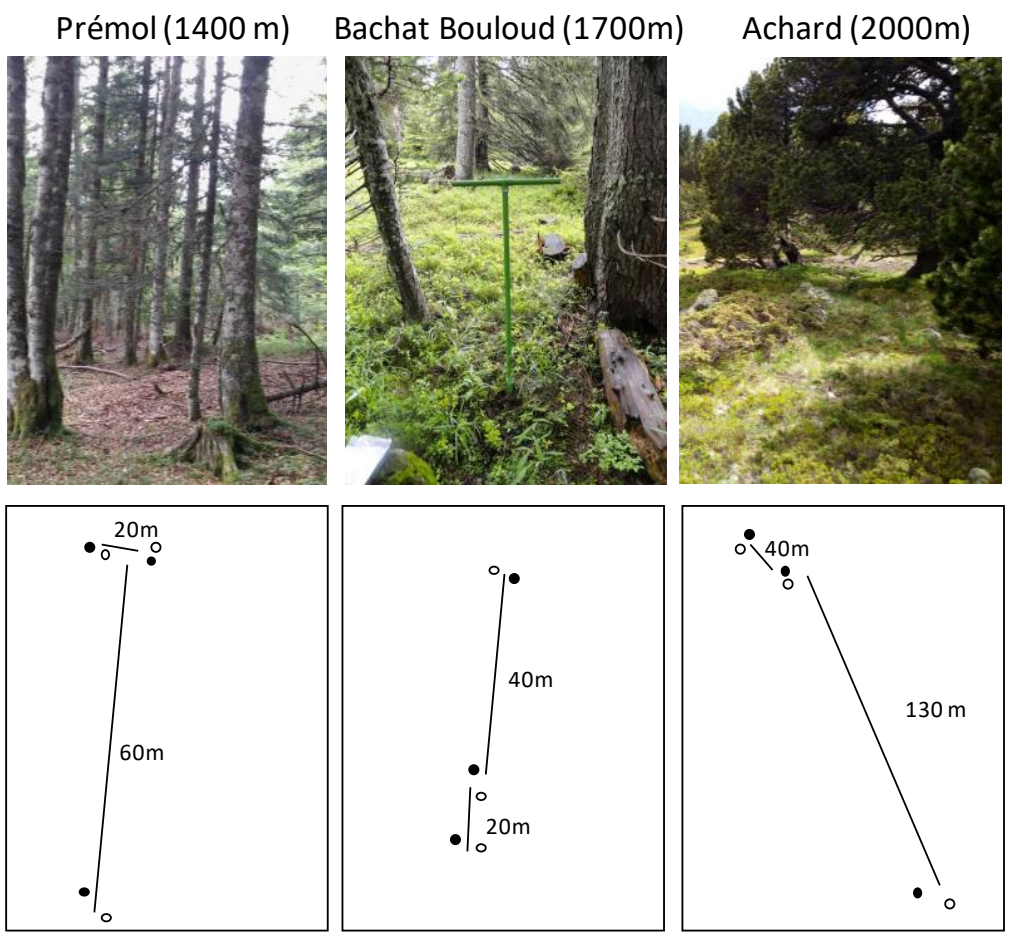

Figure 1. a) Location of the plots in the three elevations (1400, 1700 and 2000m) where samples were taken (Map data: Google, Image (02017 Digital Globe); b) pictures showing the three sites where root, soil and litter were collected for analysis and location of pairs of gaps (open circles) and closed forest (closed circles). Distances (in m), between each plot are indicated. 

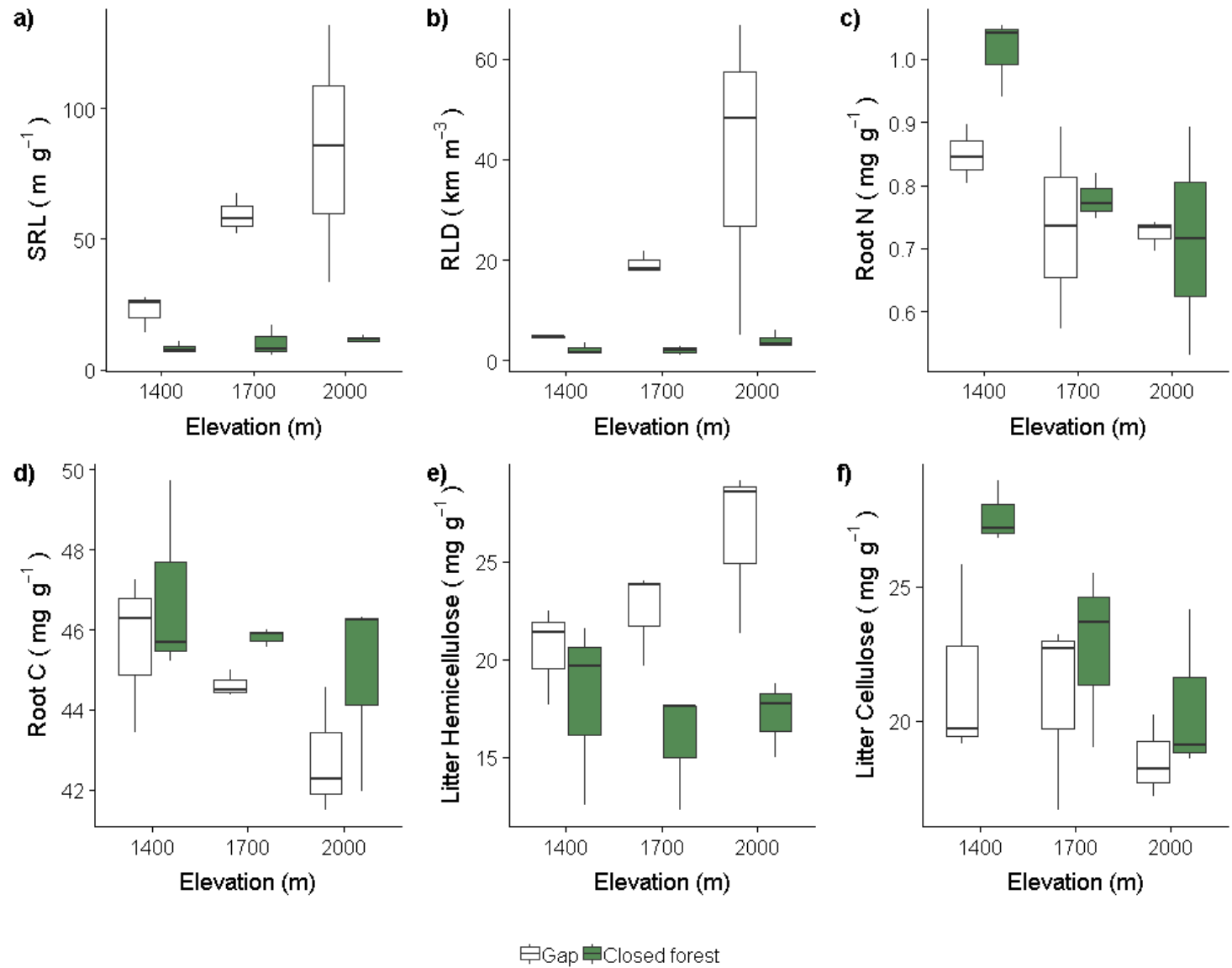

Figure 2. A selection of root and litter physical traits: (a) specific root length (SRL), (b) root length density (RLD); and chemical traits: (c) root nitrogen $(\mathrm{N})$, (d) root carbon $(\mathrm{C})$, (e) litter hemicellulose and (f) litter cellulose in gaps (white bars) and closed forest (green bars) along the elevation gradient. Boxplots represent the minimum, maximum, median, first quartile and third quartile in the data set. 

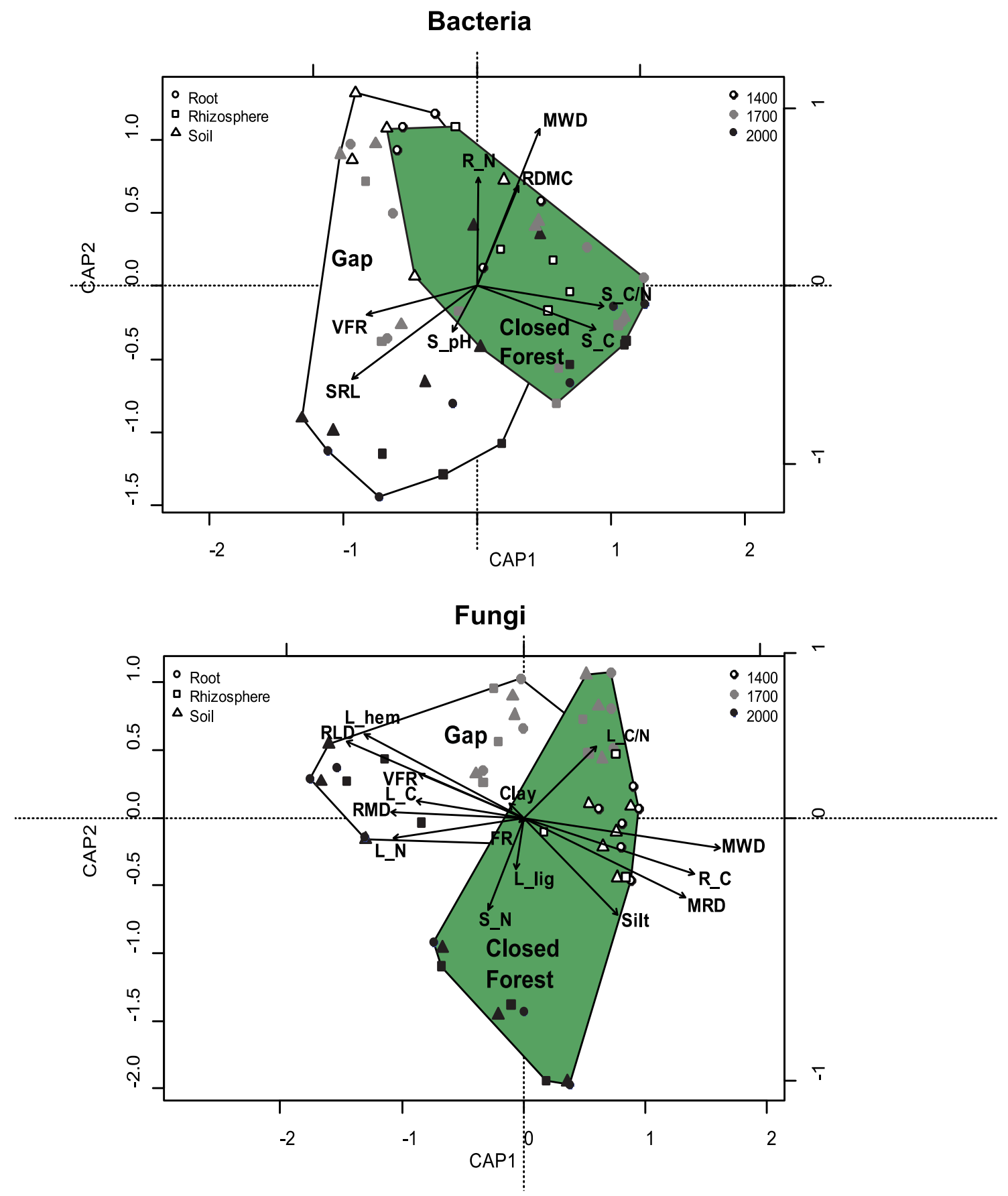

Figure 3. Graphs of dbRDA constrained ordinations of bacterial and fungal species matrices with convex hull polygons containing plots of gaps (white) and closed forest (green) and significant variables obtained by automatic backward stepwise model building. Data are shown for roots (०), rhizosphere $(\square)$ and bulk soil $(\triangle)$ fractions at $1400 \mathrm{~m}$ (white symbols), $1700 \mathrm{~m}$ (grey symbols) and $2000 \mathrm{~m}$ (black symbols). 
a) Bacteria

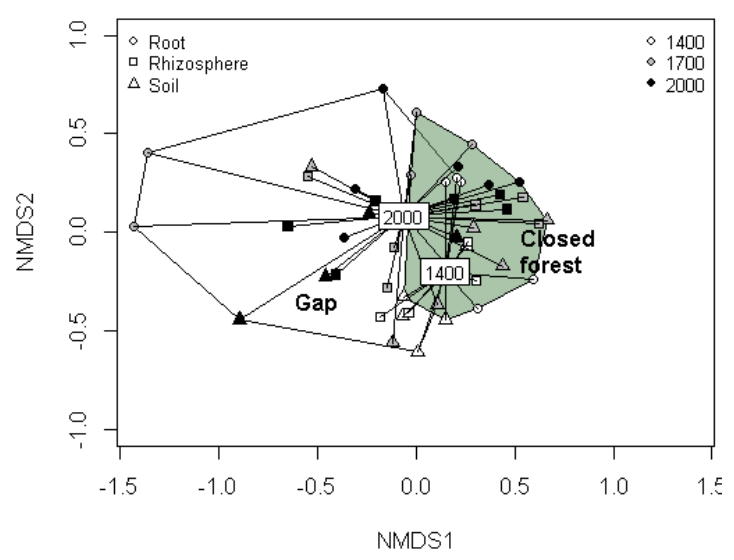

b) Fungi

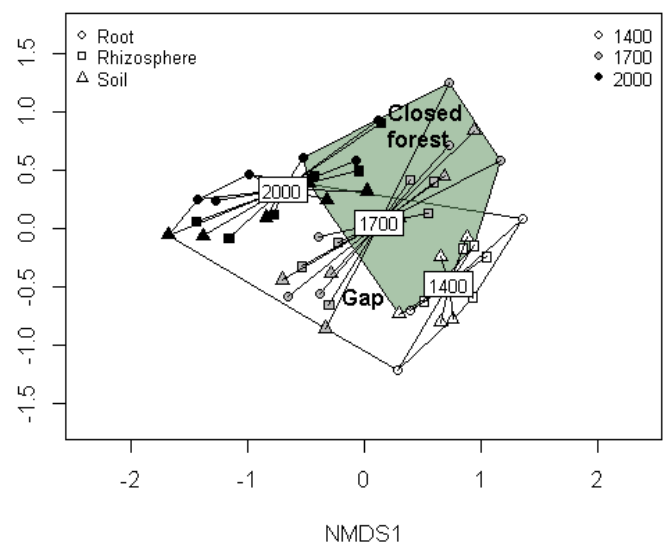

Figure 4. NMDS ordinations of a) bacterial and b) fungal species matrices with convex hull polygons containing plots of the two locations (gap and closed forest white and green shaded respectively) and spider diagrams linking plots with the same elevation (2000 and $1700 \mathrm{~m}$ tags are overlapped for bacteria). Sample fractions are shown with different symbols ( $\odot$ : root, $\square$ : rhizosphere, $\triangle$ : bulk soil). 
a)

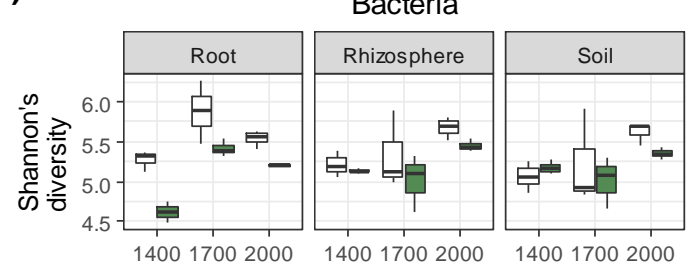

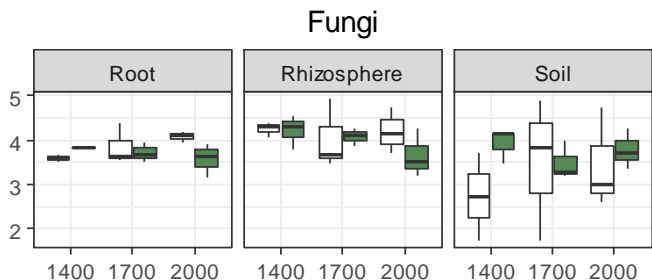

b)
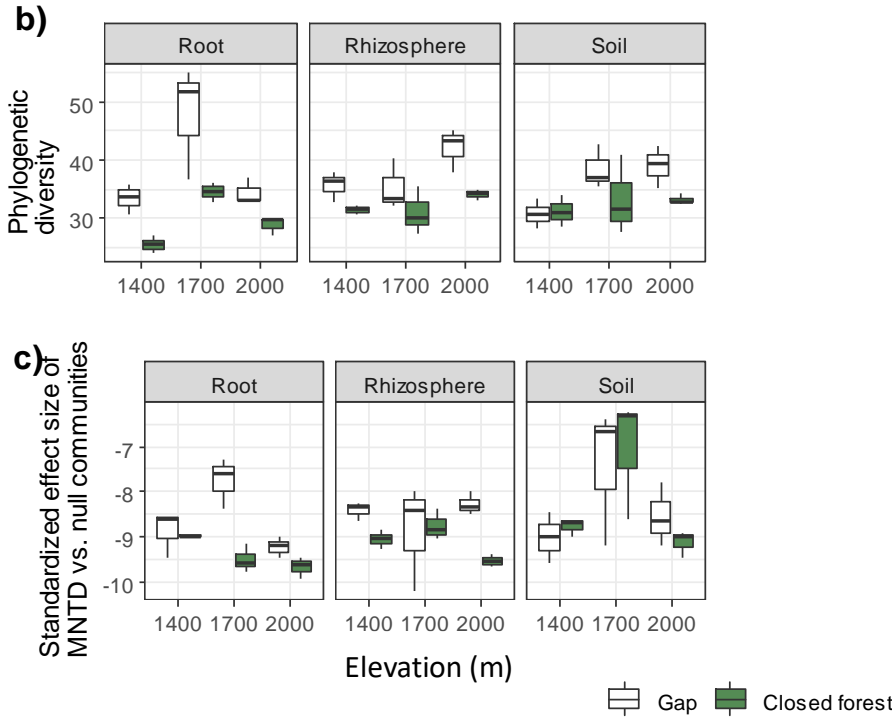

Figure 5. Changes in a) bacterial taxonomic diversity (Shannon's diversity), b) phylogenetic diversity and c) phylogenetic clustering (standardized effect size of MNTD versus null communities, ses.MNTD) in gaps (white bars) and closed forest (green bars), along the elevational gradient for the three sample fractions (root, rhizosphere and soil). Boxplots represent the minimum, maximum, median, first quartile and third quartile in the data set. 


\section{Supporting Information}

Table S1. Dominant species and abundance of herbs and trees in gaps and closed forest along the elevation gradient. Abundance of herbs and trees is given as a percentage foliar cover. Age to last disturbance (Dist) is the time (in years) to the last disturbance (tree thinning). Taken from Prieto et al. (2015).

\begin{tabular}{|c|c|c|c|c|c|}
\hline Elevation & $\begin{array}{l}\text { Land } \\
\text { use } \\
\text { type }\end{array}$ & Dominant species & $\begin{array}{l}\text { Herbs } \\
\text { (\% cover }\end{array}$ & $\begin{array}{l}\text { Trees } \\
\% \text { cover) }\end{array}$ & $\begin{array}{c}\text { Dist } \\
\text { (years) }\end{array}$ \\
\hline \multirow{2}{*}{1400} & Gap & $\begin{array}{l}\text { Galium rotundifolium L., } \\
\text { Lysimachia nemorum L., } \\
\text { Luzula nivea (Nath.) DC }\end{array}$ & 89 & 0 & 5 \\
\hline & $\begin{array}{c}\text { Closed } \\
\text { forest }\end{array}$ & $\begin{array}{l}\text { Abies alba Mill., } \\
\text { Picea abies (L.) H. Karst., } \\
\text { Fagus sylvatica L. }\end{array}$ & 10 & 90 & 40 \\
\hline \multirow[t]{2}{*}{1700} & Gap & $\begin{array}{l}\text { Luzula nivea (Nath.) DC } \\
\text { Rhododendron ferrugineum L., } \\
\text { Vaccinium myrtillus L. }\end{array}$ & 55 & 0 & 5 \\
\hline & $\begin{array}{c}\text { Closed } \\
\text { forest }\end{array}$ & $\begin{array}{l}\text { Picea abies (L.) H. Karst., } \\
\text { Abies alba Mill. }\end{array}$ & 0 & 90 & 40 \\
\hline \multirow{2}{*}{2000} & Gap & $\begin{array}{l}\text { Rhododendron ferrugineum L., } \\
\text { Vaccinium myrtillus L. }\end{array}$ & 50 & 0 & 5 \\
\hline & $\begin{array}{c}\text { Closed } \\
\text { forest }\end{array}$ & $\begin{array}{l}\text { Pinus uncinata Ramond ex. } \\
\text { DC., } \\
\text { Picea abies (L.) H. Karst. }\end{array}$ & 10 & 90 & 40 \\
\hline
\end{tabular}


Table S2. Climate and microclimate data (mean \pm standard error) along the elevation gradient in gaps and closed forest. P-values of analysis of covariance (ANCOVA) tests are shown for air and soil temperatures and Friedman tests for soil water potential. Number of repeated measures is shown between brackets. ( $* * * \mathrm{P}<0.001$, $* * \mathrm{P}<0.01$, $* \mathrm{P}<0.05)$. Post hoc comparisons performed with Nemenyi multiple tests.

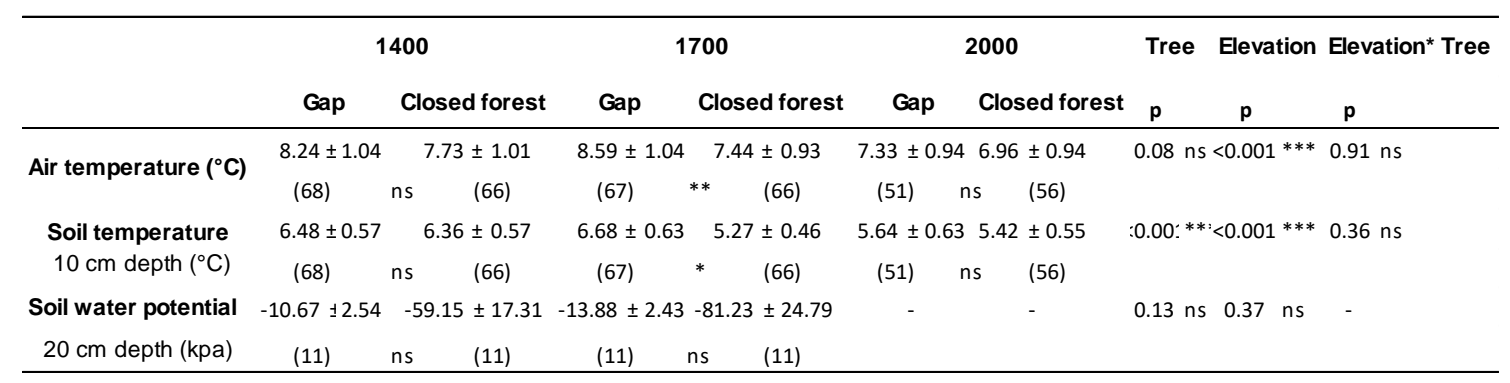


Table S3. Soil physicochemical properties along the elevation gradient in gaps and closed forest. p-values from analysis of covariance (ANCOVA) tests are shown. Two sample t-test significant results at $\mathrm{p}<0.05$ are shown with the symbol "+" for gap versus closed forest. Kruskal-Wallis and Wilcoxon test were performed for p. Refer to Table S5 for abbreviations.

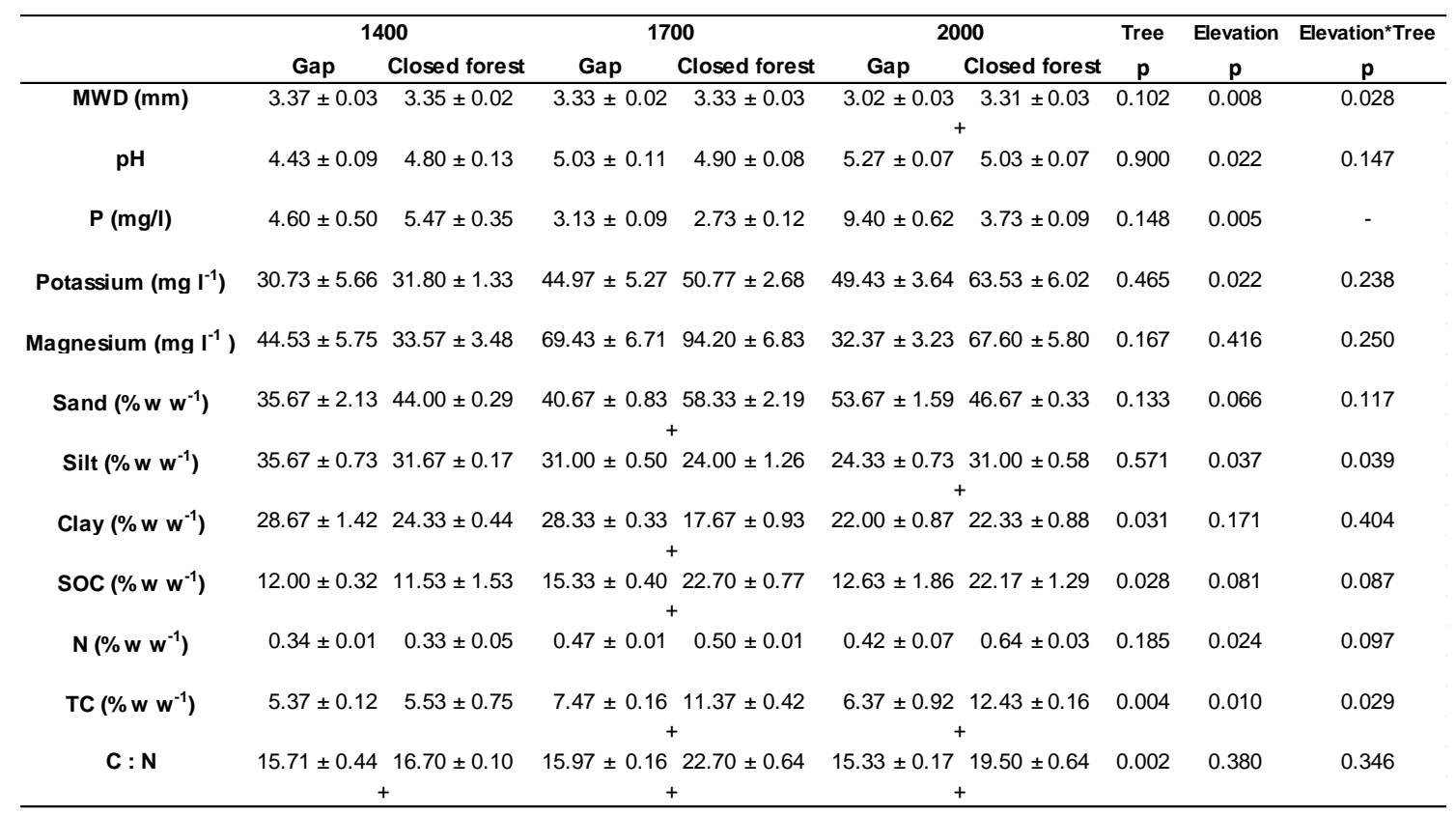


Table S4. Root and litter traits along the elevation gradient in gaps and closed forest. P-values of analysis of variance (ANOVA) tests or Kruskal Wallis are shown. Different letters show post-hoc Tukey honestly significant difference (HSD) results for elevation. Two sample t-test significant results at $p<0.05$ are shown with the symbol "+" for gap versus closed forest. Refer to Table S5 for abbreviations.

\begin{tabular}{|c|c|c|c|c|c|c|c|c|c|}
\hline & \multicolumn{2}{|c|}{1400} & \multicolumn{2}{|c|}{1700} & \multicolumn{2}{|c|}{2000} & \multirow{2}{*}{$\begin{array}{c}\text { Tree } \\
\mathbf{p}\end{array}$} & \multirow{2}{*}{$\begin{array}{c}\text { Elevation } \\
\mathbf{p}\end{array}$} & \multirow{2}{*}{$\begin{array}{c}\text { Elevation }{ }^{\star} \text { Tree } \\
p\end{array}$} \\
\hline & Gap & Closed forest & Gap & Closed forest & Gap & Closed forest & & & \\
\hline \multicolumn{10}{|l|}{ Root traits } \\
\hline SRL $\left(\mathrm{m} \mathrm{gr}^{-1}\right)$ & $22.61 \pm 4.21$ & $8.16 \pm 1.28$ & $59.20 \pm 4.49$ & $10.36 \pm 3.49$ & $83.76 \pm 28.40$ & $11.66 \pm 0.83$ & $<0.001$ & 0.005 & 0.037 \\
\hline VFR (\%) & $40.65 \pm 1.80$ & $49.69 \pm 5.30$ & $57.86 \pm 3.48$ & $39.29 \pm 6.30$ & $54.76 \pm 4.05$ & $45.41 \pm 4.39$ & 0.146 & 0.343 & 0.088 \\
\hline FR (\%) & $52.01 \pm 3.86$ & $34.66 \pm 5.79$ & $40.52 \pm 3.30$ & $46.83 \pm 4.52$ & $43.65 \pm 3.22$ & $44.81 \pm 4.67$ & 0.393 & 0.847 & 0.063 \\
\hline Mean Root Diameter (mm) & $0.40 \pm 0.03$ & $0.53 \pm 0.02$ & $0.26 \pm 0.02$ & $0.52 \pm 0.09$ & $0.27 \pm 0.03$ & $0.46 \pm 0.02$ & $<0.001$ & 0.030 & 0.499 \\
\hline RDMC ( gr gr $\left.^{-1}\right)$ & $0.37 \pm 0.01$ & $0.40 \pm 0.01$ & $0.37 \pm 0.04$ & $0.39 \pm 0.02$ & $0.33 \pm 0.01+$ & $0.37 \pm 0.02$ & 0.076 & 0.138 & 0.623 \\
\hline $\operatorname{RMD}\left(\mathrm{g} \mathrm{m}^{-3}\right)$ & $228.65 \pm 56.37$ & $272.16 \pm 37.30$ & $332.37 \pm 44.57$ & $211.41 \pm 31.25$ & $406.38 \pm 128.18$ & $341.92 \pm 65.62$ & 0.086 & 0.402 & 0.434 \\
\hline $\operatorname{RLD}\left(\mathrm{km} \mathrm{m}^{-3}\right)$ & $4.70 \pm 0.13$ & $2.30 \pm 0.67$ & $19.30 \pm 1.22$ & $2.05 \pm 0.47$ & $40.01 \pm 18.25$ & $4.05 \pm 1.01$ & 0.001 & 0.264 & - \\
\hline Lignin $\left(\mathrm{mg} \mathrm{g}^{-1}\right)$ & 46.04 & 54.56 & 63.37 & 54.67 & 50.36 & 59.74 & - & - & - \\
\hline Cellulose $\left(\mathrm{mg} \mathrm{g}^{-1}\right)$ & 27.90 & 22.61 & 18.75 & 21.82 & 19.61 & 16.16 & - & - & - \\
\hline Hemicellulose $\left(\mathrm{mg} \mathrm{g}^{-1}\right)$ & 21.97 & 17.67 & 17.47 & 19.00 & 31.05 & 16.87 & - & - & - \\
\hline$N\left(\mathrm{mg} \mathrm{g}^{-1}\right)$ & $0.85 \pm 0.03$ & $1.01 \pm 0.04$ & $0.73 \pm 0.09$ & $0.78 \pm 0.02$ & $0.72 \pm 0.01$ & $0.71 \pm 0.10$ & 0.200 & 0.003 & 0.170 \\
\hline$C(\mathrm{mg} / \mathrm{g})$ & $45.67 \pm 1.15$ & $46.88 \pm 1.43$ & $44.63 \pm 0.19$ & $45.82 \pm 0.14$ & $42.78 \pm 0.92$ & $44.85 \pm 1.44$ & 0.022 & 0.077 & 0.662 \\
\hline$C: N$ & $54.01 \pm 3.03$ & $46.39 \pm 1.52$ & $62.89 \pm 8.12$ & $58.92 \pm 1.41$ & $59.13 \pm 1.58$ & $65.16 \pm 7.85$ & 0.643 & 0.026 & 0.176 \\
\hline \multicolumn{10}{|l|}{ Litter traits } \\
\hline Lignin $\left(\mathrm{mg} \mathrm{g}^{-1}\right)$ & $47.10 \pm 2.45$ & $45.57 \pm 2.66$ & $49.11 \pm 1.74$ & $51.53 \pm 3.71$ & $48.79 \pm 2.81$ & $51.21 \pm 1.38$ & 0.595 & 0.164 & 0.442 \\
\hline Cellulose $\left(\mathrm{mg} \mathrm{g}^{-1}\right)$ & $21.57 \pm 2.15$ & $27.67 \pm 0.66$ & $20.87 \pm 2.11$ & $22.73 \pm 1.95$ & $18.54 \pm 0.89$ & $20.61 \pm 1.79$ & 0.023 & 0.007 & 0.231 \\
\hline Hemicellulose $\left(\mathrm{mg} \mathrm{g}^{-1}\right)$ & $20.50 \pm 1.47$ & $17.93 \pm 2.74$ & $22.49 \pm 1.41$ & $15.84 \pm 1.77$ & $26.34 \pm 2.52$ & $17.16 \pm 1.13$ & 0.004 & 0.751 & - \\
\hline$N\left(\mathrm{mg} \mathrm{g}^{-1}\right)$ & $1.16 \pm 0.02$ & $0.84 \pm 0.06$ & $0.95 \pm 0.21$ & $0.92 \pm 0.21$ & $1.70 \pm 0.53$ & $1.12 \pm 0.10$ & 0.122 & 0.240 & - \\
\hline$C\left(\mathrm{mg} \mathrm{g}^{-1}\right)$ & $40.97 \pm 1.13$ & $38.72 \pm 2.18$ & $37.93 \pm 3.56$ & $43.09 \pm 1.15$ & $52.63 \pm 12.92$ & $40.41 \pm 1.18$ & 0.825 & 0.864 & - \\
\hline$C: N$ & $35.44 \pm 0.42$ & $46.87 \pm 5.68$ & $44.12 \pm 10.09$ & $53.96 \pm 15.69$ & $33.05 \pm 4.88$ & $36.68 \pm 2.56$ & 0.058 & 0.386 & - \\
\hline
\end{tabular}


549 Table S5. Abbreviations used in this paper

\begin{tabular}{lll}
\hline Variable & abbreviation & units \\
\hline Soil properties & & $\mathrm{mm}$ \\
\hline Mean weight diameter & MWD & $\mathrm{mg} \cdot \mathrm{l}^{-1}$ \\
P & Phosphorus & $\% \mathrm{w} \cdot \mathrm{w}^{-1}$ \\
Soil organic carbon & SOC & $\% \mathrm{w} \cdot \mathrm{w}-1$ \\
Total carbon & TC & \\
\hline Root traits & & $\mathrm{m} \cdot \mathrm{g}^{-1}$ \\
\hline Specific root length & SRL & $\%$ \\
Very fine roots & VFR & $\%$ \\
Fine roots & FR & $\mathrm{mm}$ \\
Mean Root Diameter & MRD & $\mathrm{mg} \cdot \mathrm{g}^{-1}$ \\
Root dry matter content & RDMC & $\mathrm{g} \cdot \mathrm{m}^{-3}$ \\
Root mass density & RMD & $\mathrm{km} \cdot \mathrm{m}^{-3}$ \\
Root length density & RLD & \\
\hline General abbreviations & & $\% \mathrm{w} \cdot \mathrm{w}^{-1}$ \\
\hline Nitrogen & $\mathrm{N}$ & $\% \mathrm{w} \cdot \mathrm{w}^{-1}$ \\
Carbon & $\mathrm{C}$ & $\mathrm{none}$ \\
C-to-N ratio & C:N & $\mathrm{none}$ \\
Shannon's diversity & $\mathrm{H}$ & $\mathrm{none}$ \\
Faith's Phylogenetic Diversity & PD & $\mathrm{none}$ \\
Standardized mean nearest taxon distance & Ses.MNTD & \\
\hline
\end{tabular}




\section{Bacteria (16S)}
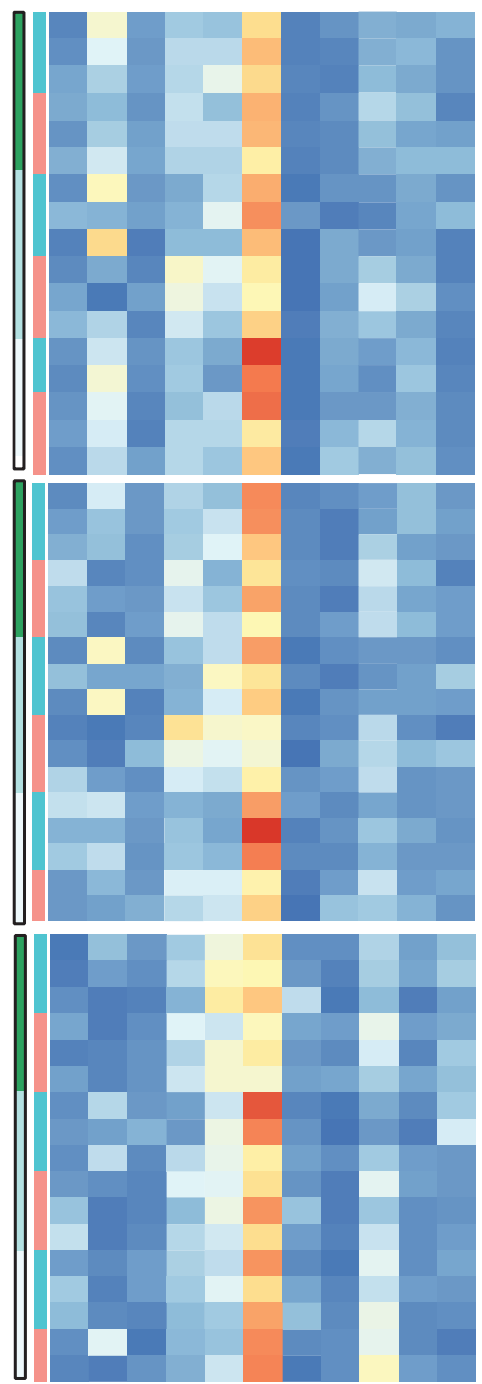

Fungi (ITS)

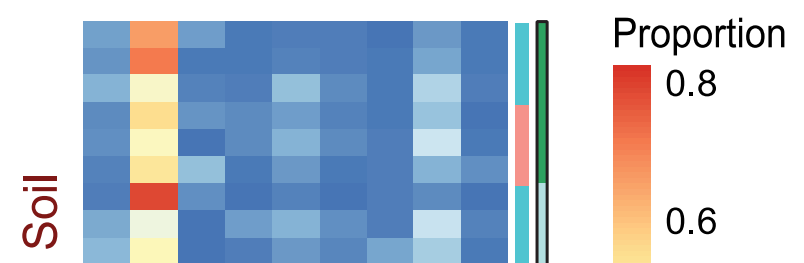

产

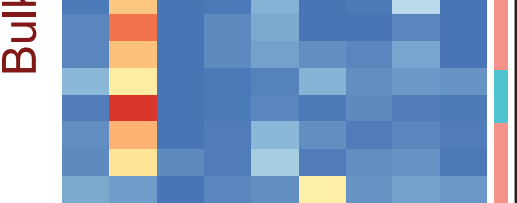

0.4

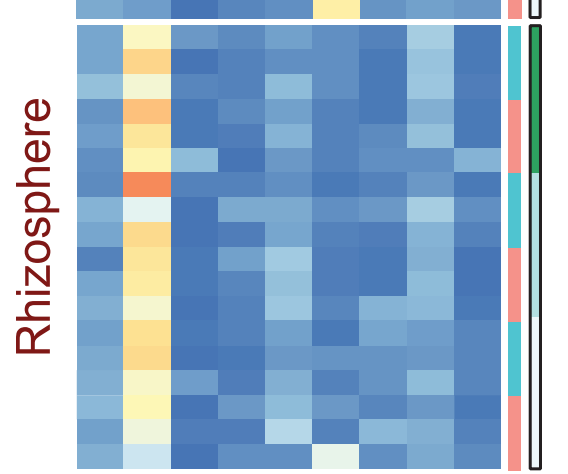

0.2

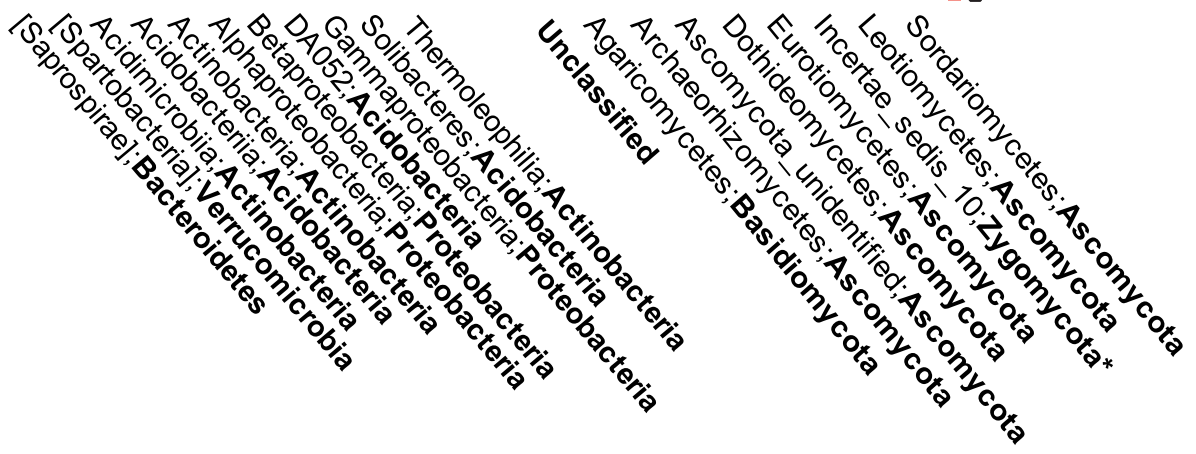

Fig. S1. Phylum and class of bacterial and fungal communities along the elevation and in gaps and closed forest. Proportion of presence within sampling unit. Only the most abundant classes are shown (for which the sum of proportions for all sites were greater than one). *Zygomycota assignation here was before their later reclassification among Glomeromycota and several subphyla incertae sedis (Hibbett et al. 2007). 
A

Gap

Closed forest
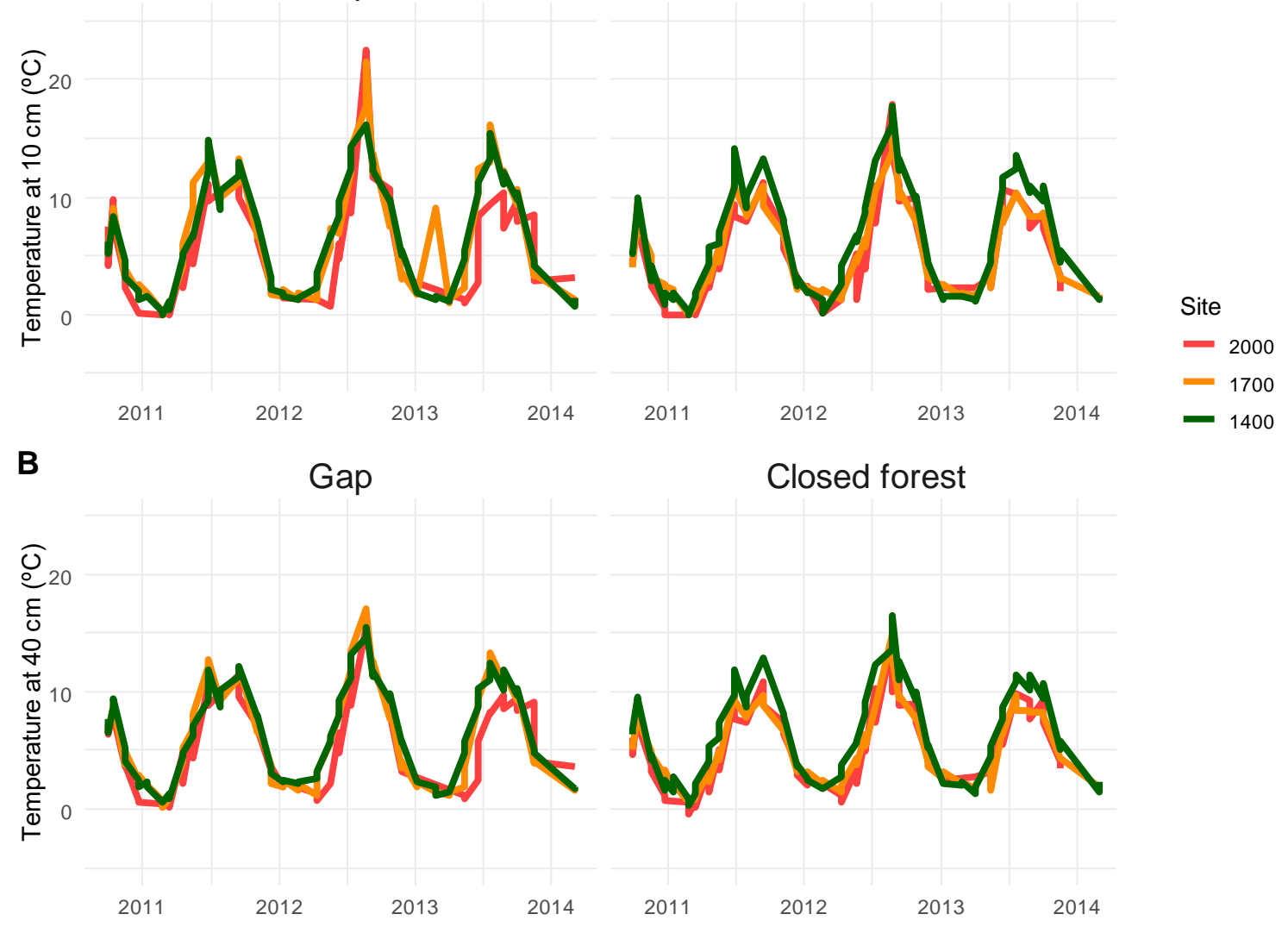

Time

Fig. S2. Soil temperature data in gaps and closed forest, over time and for the three elevations: a) soil temperature at a depth of $10 \mathrm{~cm}$ and b) soil temperature at a depth of $40 \mathrm{~cm}$. 
Notes S1 Additional methodological details on Illumina amplicon sequencing of 16S rRNA genes and the ITS region.

Amplicons were generated using a high-fidelity DNA polymerase (Q5 Taq, New England Biolabs) and pooled. PCR was conducted on $20 \mathrm{ng}$ of template DNA employing an initial denaturation of 30 seconds at $95^{\circ} \mathrm{C}$, followed by cycles ( 25 for $16 \mathrm{~S}$ and 30 for ITS) of 30 seconds at $95{ }^{\circ} \mathrm{C}, 30$ seconds at $52{ }^{\circ} \mathrm{C}$ and 2 minutes at $72{ }^{\circ} \mathrm{C}$. A final extension of 10 minutes at $72{ }^{\circ} \mathrm{C}$ was also included to complete the reaction. Amplicon sizes were determined using an Agilent 2200 TapeStation system ( 550bp:16S; 350-425: ITS; 650:18S) and libraries normalized using SequalPrep Normalization Plate Kit (Thermo Fisher Scientific). Library concentration was calculated using a SYBR green quantitative PCR (qPCR) assay with primers specific to the Illumina adapters (Kappa, Anachem). Libraries were sequenced at a concentration of $5.4 \mathrm{pM}$ with a $0.6 \mathrm{pM}$ addition of an Illumina generated PhiX control library. Sequencing runs, generating $2 \mathrm{x}$ $300 \mathrm{bp}$, reads were performed on an Illumina MiSeq using V3 chemistry. The read 1 (R1), read 2 (R2) and index sequencing primers used were also gene specific: $\mathrm{R} 1=$ sequence of the combined pad, linker and forward primer (e.g. 314F; 16S) or; R2 = sequence of the combined pad, linker and reverse primer (e.g. 806R; 16S); I = reverse compliment of the $\mathrm{R} 2$ primer. 
Aponte C, García LV, Marañón T (2013) Tree species effects on nutrient cycling and soil biota: A feedback mechanism favouring species coexistence. For Ecol Manage 309:36-46

Bach LH, Grytnes J-A, Halvorsen R, Ohlson M (2010) Tree influence on soil microbial community structure. Soil Biol Biochem 42:1934-1943

Bahram M, Polme S, Koljalg U, Zarre S, Tedersoo L (2012) Regional and local patterns of ectomycorrhizal fungal diversity and community structure along an altitudinal gradient in the Hyrcanian forests of northern Iran. New Phytol 193:465-473

Baldrian P (2017) Forest microbiome: diversity, complexity and dynamics. FEMS Microbiol Rev 41:109130

Bardgett RD, Mommer L, De Vries FT (2014) Going underground: root traits as drivers of ecosystem processes. Trends Ecol Evol 29:692-699

Baumert VL, Vasilyeva NA, Vladimirov AA, Meier IC, Kögel-Knabner I, Mueller CW (2018) Root Exudates Induce Soil Macroaggregation Facilitated by Fungi in Subsoil. Front Environ Sci 6

Bever JD, Platt TG, Morton ER (2012) Microbial population and community dynamics on plant roots and their feedbacks on plant communities. Annu Rev Microbiol 66:265-283

Brant JB, Myrold DD, Sulzman EW (2006) Root controls on soil microbial community structure in forest soils. Oecologia 148:650-659

Brundrett MC (2002) Coevolution of roots and mycorrhizas of land plants. New Phytol 154:275-304

Bryant JA, Lamanna C, Morlon H, Kerkhoff AJ, Enquist BJ, Green JL (2008) Microbes on mountainsides: Contrasting elevational patterns of bacterial and plant diversity. PNAS 105:11505-11511

Bulgarelli D, Garrido-Oter R, Münch Philipp C, Weiman A, Dröge J, Pan Y, McHardy Alice C, SchulzeLefert P (2015) Structure and Function of the Bacterial Root Microbiota in Wild and Domesticated Barley. Cell Host \& Microbe 17:392-403

Bulgarelli D, Rott M, Schlaeppi K, Ver Loren van Themaat E, Ahmadinejad N, Assenza F, Rauf P, Huettel B, Reinhardt R, Schmelzer E, Peplies J, Gloeckner FO, Amann R, Eickhorst T, SchulzeLefert P (2012) Revealing structure and assembly cues for Arabidopsis root-inhabiting bacterial microbiota. Nature 488:91-95

Caporaso JG, Bittinger K, Bushman FD, DeSantis TZ, Andersen GL, Knight R (2010) PyNAST: a flexible tool for aligning sequences to a template alignment. Bioinformatics 26:266-267

Chenu C, Sotzky G (2002) Interactions Between Microorganisms and Soil Particles. In: Interactions between soil particles and microorganisms. IUPAC series of Applied Chemistry. pp 3-40.

Coince A, Cordier T, Lengellé J, Defossez E, Vacher C, Robin C, Buée M, Marçais B (2014) Leaf and Root-Associated Fungal Assemblages Do Not Follow Similar Elevational Diversity Patterns. PLOS ONE 9:e100668

Colin Y, Nicolitch O, Van Nostrand JD, Zhou JZ, Turpault MP, Uroz S (2017) Taxonomic and functional shifts in the beech rhizosphere microbiome across a natural soil toposequence. Sci Rep 7:9604

Collins CG, Stajich JE, Weber SE, Pombubpa N, Diez JM (2018) Shrub range expansion alters diversity and distribution of soil fungal communities across an alpine elevation gradient. Mol Ecol

de Freitas CR, Enright NJ (1995) Microclimatic differences between and within canopy gaps in a temperate rainforest. International Journal of Biometeorology 38:188-193

de Graaff MA, Classen AT, Castro HF, Schadt CW (2010) Labile soil carbon inputs mediate the soil microbial community composition and plant residue decomposition rates. New Phytol 188:10551064

Dean WE (1974) Determination of carbonate and organic matter in calcareous sediments and sedimentary rocks by loss on ignition; comparison with other methods. J Sediment Res 44:242-248

DeSantis TZ, Hugenholtz P, Larsen N, Rojas M, Brodie EL, Keller K, Huber T, Dalevi D, Hu P, Andersen GL (2006a) Greengenes, a chimera-checked 16S rRNA gene database and workbench compatible with ARB. Appl Environ Microbiol 72:5069-5072

DeSantis TZ, Hugenholtz P, Larsen N, Rojas M, Brodie EL, Keller K, Huber T, Dalevi D, Hu P, Andersen GL (2006b) Greengenes, a Chimera-Checked 16S rRNA Gene Database and Workbench Compatible with ARB. Applied and Environmental Microbiology 72:5069-5072

Dray S, Dufour A-B (2007) The ade4 Package: Implementing the Duality Diagram for Ecologists. Journal of Statistical Software 22:1-20

Dukunde A, Schneider D, Schmidt M, Veldkamp E, Daniel R (2019) Tree Species Shape Soil Bacterial Community Structure and Function in Temperate Deciduous Forests. Front Microbiol 10

Faith DP (1992) Conservation evaluation and phylogenetic diversity. Biological Conservation 61:1-10 
Gale WJ, Cambardella CA, Bailey TB (2000) Root-derived carbon and the formation and stabilization of aggregates. Soil Sci Soc Am J 64:201-207

Goberna M, García C, Verdú M (2014a) A role for biotic filtering in driving phylogenetic clustering in soil bacterial communities. Global Ecol Biogeogr 23:1346-1355

Goberna M, Navarro-Cano JA, Valiente-Banuet A, García C, Verdú M (2014b) Abiotic stress tolerance and competition-related traits underlie phylogenetic clustering in soil bacterial communities. Ecol Lett 17:1191-1201

Gray AN, Spies TA, Easter MJ (2002) Microclimatic and soil moisture responses to gap formation in coastal Douglas-fir forests. Can J For Res 32:332-343

Grigulis K, Lavorel S, Krainer U, Legay N, Baxendale C, Dumont M, Kastl E, Arnoldi C, Bardgett RD, Poly F, Pommier T, Schloter M, Tappeiner U, Bahn M, Clément J-C (2013) Relative contributions of plant traits and soil microbial properties to mountain grassland ecosystem services. J Ecol 101:47-57

Gweon HS, Oliver A, Taylor J, Booth T, Gibbs M, Read DS, Griffiths RI, Schonrogge K (2015) PIPITS: an automated pipeline for analyses of fungal internal transcribed spacer sequences from the Illumina sequencing platform. Methods Ecol Evol 6:973-980

Hibbett DS, Binder M, Bischoff JF, Blackwell M, Cannon PF, Eriksson OE, Huhndorf S, James T, Kirk PM, Lücking R, Thorsten Lumbsch H, Lutzoni F, Matheny PB, McLaughlin DJ, Powell MJ, Redhead S, Schoch CL, Spatafora JW, Stalpers JA, Vilgalys R, Aime MC, Aptroot A, Bauer R, Begerow D, Benny GL, Castlebury LA, Crous PW, Dai Y-C, Gams W, Geiser DM, Griffith GW, Gueidan C, Hawksworth DL, Hestmark G, Hosaka K, Humber RA, Hyde KD, Ironside JE, Kõljalg U, Kurtzman CP, Larsson K-H, Lichtwardt R, Longcore J, Miądlikowska J, Miller A, Moncalvo J-M, Mozley-Standridge S, Oberwinkler F, Parmasto E, Reeb V, Rogers JD, Roux C, Ryvarden L, Sampaio JP, Schüßler A, Sugiyama J, Thorn RG, Tibell L, Untereiner WA, Walker C, Wang Z, Weir A, Weiss M, White MM, Winka K, Yao Y-J, Zhang N (2007) A higher-level phylogenetic classification of the Fungi. Mycol Res 111:509-547

Horner-Devine MC, Bohannan BJM (2006) Phylogenetic clustering and overdispersion in bacterial communities. Ecology 87:S100-S108

Hornung M (1985) Acidification of soils by trees and forests. Soil Use Manag 1:24-27

Ihrmark K, Bodeker IT, Cruz-Martinez K, Friberg H, Kubartova A, Schenck J, Strid Y, Stenlid J, Brandstrom-Durling M, Clemmensen KE, Lindahl BD (2012) New primers to amplify the fungal ITS2 region--evaluation by 454-sequencing of artificial and natural communities. FEMS Microbiol Ecol 82:666-677

IWG W (2007) World reference base for soil resources 2006, first update 2007. FAO, Rome

Jarvis SG, Woodward S, Taylor AF (2015) Strong altitudinal partitioning in the distributions of ectomycorrhizal fungi along a short $(300 \mathrm{~m})$ elevation gradient. New Phytol 206:1145-1155

Jonard M, Nicolas M, Coomes DA, Caignet I, Saenger A, Ponette Q (2017) Forest soils in France are sequestering substantial amounts of carbon. Sci Total Environ 574:616-628

Joud D (2006) Guide pour identifier les stations forestières de Rhône-Alpes-Synthèse pour les Alpes du Nord et les montagnes de l'Ain. In: Rhône-Alpes C (ed). p 132.

Kembel SW, Cowan PD, Helmus MR, Cornwell WK, Morlon H, Ackerly DD, Blomberg SP, Webb CO (2010) Picante: R tools for integrating phylogenies and ecology. Bioinformatics 26:1463-1464

Kernaghan G, Harper KA (2001) Community structure of ectomycorrhizal fungi across an alpine/subalpine ecotone. Ecography 24:181-188

Kohout P, Charvátová M, Štursová M, Mašínová T, Tomšovský M, Baldrian P (2018) Clearcutting alters decomposition processes and initiates complex restructuring of fungal communities in soil and tree roots. ISME J

Koljalg U, Nilsson RH, Abarenkov K, Tedersoo L, Taylor AF, Bahram M, Bates ST, Bruns TD, Bengtsson-Palme J, Callaghan TM, Douglas B, Drenkhan T, Eberhardt U, Duenas M, Grebenc T, Griffith GW, Hartmann M, Kirk PM, Kohout P, Larsson E, Lindahl BD, Lucking R, Martin MP, Matheny PB, Nguyen NH, Niskanen T, Oja J, Peay KG, Peintner U, Peterson M, Poldmaa K, Saag L, Saar I, Schussler A, Scott JA, Senes C, Smith ME, Suija A, Taylor DL, Telleria MT, Weiss M, Larsson KH (2013) Towards a unified paradigm for sequence-based identification of fungi. Mol Ecol 22:5271-5277

Körner C (2007) The use of 'altitude' in ecological research. Trends Ecol Evol 22:569-574

Kozich JJ, Westcott SL, Baxter NT, Highlander SK, Schloss PD (2013) Development of a dual-index sequencing strategy and curation pipeline for analyzing amplicon sequence data on the MiSeq Illumina sequencing platform. Appl Environ Microbiol 79:5112-5120

Kuzyakov Y, Blagodatskaya E (2015) Microbial hotspots and hot moments in soil: Concept \& review. Soil Biol Biochem 83:184-199 
Lareen A, Burton F, Schafer P (2016) Plant root-microbe communication in shaping root microbiomes. Plant Mol Biol 90:575-587

Le Bissonnais Y (1996) Aggregate stability and assessment of soil crustability and erodibility: I. Theory and methodology. Eur J Soil Sci 47:425-437

Lehmann A, Zheng W, Rillig MC (2017) Soil biota contributions to soil aggregation. Nat Ecol Evol

Liu J, Ngoc Ha V, Shen Z, Dang P, Zhu H, Zhao F, Zhao Z (2018) Response of the rhizosphere microbial community to fine root and soil parameters following Robinia pseudoacacia L. afforestation. Appl Soil Ecol 132:11-19

Lladó S, López-Mondéjar R, Baldrian P (2018) Drivers of microbial community structure in forest soils. Appl Microbiol Biotechnol 102:4331-4338

Mao Z, Jourdan C, Bonis M-L, Pailler F, Rey H, Saint-André L, Stokes A (2013) Modelling root demography in heterogeneous mountain forests and applications for slope stability analysis. Plant Soil 363:357-382

Mao Z, Saint-André L, Genet M, Mine FX, Jourdan C, Rey H, Courbaud B, Stokes A (2012) Engineering ecological protection against landslides in diverse mountain forests: Choosing cohesion models. Ecol Eng 45:55-69

Mao Z, Wang Y, Jourdan C, Cécillon L, Nespoulous J, Rey H, Saint-André L, Stokes A (2015) Characterizing Above- and Belowground Carbon Partitioning in Forest Trees along an Altitudinal Gradient using Area-Based Indicators. Arct Antarct Alp Res 47:59-69

Mayfield MM, Levine JM (2010) Opposing effects of competitive exclusion on the phylogenetic structure of communities. Ecol Lett 13:1085-1093

McCain CM, Grytnes J-A (2010) Elevational Gradients in Species Richness. In: Encyclopedia of Life Sciences (ELS). John Wiley \& Sons, Ltd.

McCave IN, Bryant RJ, Cook HF, Coughanowr CA (1986) Evaluation of a laser-diffraction-size analyzer for use with natural sediments. J Sediment Res 56:561-564

Miller RM, Jastrow JD (1990) Hierarchy of root and mycorrhizal fungal interactions with soil aggregation. Soil Biology and Biochemistry 22:579-584

Miyamoto Y, Nakano T, Hattori M, Nara K (2014) The mid-domain effect in ectomycorrhizal fungi: range overlap along an elevation gradient on Mount Fuji, Japan. Isme j 8:1739-1746

Muscolo A, Bagnato S, Sidari M, Mercurio R (2014) A review of the roles of forest canopy gaps. J For Res 25:725-736

Muscolo A, Sidari M, Mercurio R (2007) Influence of gap size on organic matter decomposition, microbial biomass and nutrient cycle in Calabrian pine (Pinus laricio, Poiret) stands. For Ecol Manage 242:412-418

Oksanen J, Blanchet FG, Friendly M, Kindt R, Legendre P, McGlinn D, Minchin PR, O'Hara RB, Simpson GL, Solymos P, Stevens MHH, Szoecs E, Wagner H (2016) vegan: Community Ecology Package. R package version 2.4-0. https://CRAN.R-project.org/package=vegan.

Olsen SR, Cole CV, Watanabe FS, Dean LA, United S, Department of A (1954) Estimation of available phosphorus in soils by extraction with sodium bicarbonate. U.S. Dept. of Agriculture, Washington, D.C.

Ostonen I, Truu M, Helmisaari HS, Lukac M, Borken W, Vanguelova E, Godbold DL, Lohmus K, Zang U, Tedersoo L, Preem JK, Rosenvald K, Aosaar J, Armolaitis K, Frey J, Kabral N, Kukumagi M, Leppalammi-Kujansuu J, Lindroos AJ, Merila P, Napa U, Nojd P, Parts K, Uri V, Varik M, Truu J (2017) Adaptive root foraging strategies along a boreal-temperate forest gradient. New Phytol 215:977-991

Parks DH, Beiko RG (2013) Measures of phylogenetic differentiation provide robust and complementary insights into microbial communities. ISME J 7:173-183

Philippot L, Raaijmakers JM, Lemanceau P, van der Putten WH (2013) Going back to the roots: the microbial ecology of the rhizosphere. Nat Rev Microbiol 11:789-799

Poirier V, Roumet C, Angers DA, Munson AD (2018) Species and root traits impact macroaggregation in the rhizospheric soil of a Mediterranean common garden experiment. Plant Soil 424:289-302

Prescott CE, Grayston SJ (2013) Tree species influence on microbial communities in litter and soil: Current knowledge and research needs. For Ecol Manage 309:19-27

Price MN, Dehal PS, Arkin AP (2010) FastTree 2 - Approximately Maximum-Likelihood Trees for Large Alignments. PLOS ONE 5:e9490

Prieto I, Roumet C, Cardinael R, Dupraz C, Jourdan C, Kim JH, Maeght JL, Mao Z, Pierret A, Portillo N, Roupsard O, Thammahacksa C, Stokes A, Cahill J (2015) Root functional parameters along a land - use gradient: evidence of a community - level economics spectrum. J Ecol 103:361-373 
Ren C, Zhang W, Zhong Z, Han X, Yang G, Feng Y, Ren G (2018) Differential responses of soil microbial biomass, diversity, and compositions to altitudinal gradients depend on plant and soil characteristics. Sci Total Environ 610-611:750-758

Rognes T, Flouri T, Nichols B, Quince C, Mahé F (2016) VSEARCH: a versatile open source tool for metagenomics. PeerJ 4:e2584

RStudio Team (2016) RStudio: Integrated Development for R. RStudio Inc., Boston, MA URL

Saetre P, Bååth E (2000) Spatial variation and patterns of soil microbial community structure in a mixed spruce-birch stand. Soil Biol Biochem 32:909-917

Schneider T, Keiblinger KM, Schmid E, Sterflinger-Gleixner K, Ellersdorfer G, Roschitzki B, Richter A, Eberl L, Zechmeister-Boltenstern S, Riedel K (2012) Who is who in litter decomposition? Metaproteomics reveals major microbial players and their biogeochemical functions. ISME J 6:1749-1762

Shea F, Watts CE (1939) Dumas method for organic nitrogen. Industrial \& Engineering Chemistry Analytical Edition 11:333-334

Shen C, Liang W, Shi Y, Lin X, Zhang H, Wu X, Xie G, Chain P, Grogan P, Chu H (2014) Contrasting elevational diversity patterns between eukaryotic soil microbes and plants. Ecology 95:31903202

Shi S, O'Callaghan M, Jones EE, Richardson AE, Walter C, Stewart A, Condron L (2012) Investigation of organic anions in tree root exudates and rhizosphere microbial communities using in situ and destructive sampling techniques. Plant Soil 359:149-163

Siles JA, Margesin R (2016) Abundance and Diversity of Bacterial, Archaeal, and Fungal Communities Along an Altitudinal Gradient in Alpine Forest Soils: What Are the Driving Factors? Microb Ecol 72:207-220

Singh D, Takahashi K, Kim M, Chun J, Adams JM (2012) A hump-backed trend in bacterial diversity with elevation on Mount Fuji, Japan. Microb Ecol 63:429-437

Tindall BJ, Rossello-Mora R, Busse HJ, Ludwig W, Kampfer P (2010) Notes on the characterization of prokaryote strains for taxonomic purposes. International journal of systematic and evolutionary microbiology 60:249-266

Tisdall JM, Oades JM (1982) Organic matter and water-stable aggregates in soils. J Soil Sci 33:141-163

Urbanová M, Šnajdr J, Baldrian P (2015) Composition of fungal and bacterial communities in forest litter and soil is largely determined by dominant trees. Soil Biol Biochem 84:53-64

Uren NC (2000) Types, amounts, and possible functions of compounds released into the rhizosphere by soil-grown plants. In: The rhizosphere. CRC Press, pp 35-56.

Uroz S, Buée M, Murat C, Frey-Klett P, Martin F (2010) Pyrosequencing reveals a contrasted bacterial diversity between oak rhizosphere and surrounding soil. Environ Microbiol Rep 2:281-288

Uroz S, Oger P, Tisserand E, Cébron A, Turpault MP, Buée M, De Boer W, Leveau JHJ, Frey-Klett P (2016) Specific impacts of beech and Norway spruce on the structure and diversity of the rhizosphere and soil microbial communities. Sci Rep 6:27756

van der Putten WH, Bardgett RD, Bever JD, Bezemer TM, Casper BB, Fukami T, Kardol P, Klironomos JN, Kulmatiski A, Schweitzer JA, Suding KN, Van de Voorde TFJ, Wardle DA (2013) Plantsoil feedbacks: the past, the present and future challenges. J Ecol 101:265-276

Van Soest PJ (1963) Use of detergents in the analysis of fibrous feeds. 2. A rapid method for the determination of fiber and lignin. Journal of the Association of Official Agricultural Chemists 46:829-835

Wang J, Soininen J, He J, Shen J (2012) Phylogenetic clustering increases with elevation for microbes. Environ Microbiol Rep 4:217-226

Wang Q, Garrity GM, Tiedje JM, Cole JR (2007) Naïve Bayesian Classifier for Rapid Assignment of rRNA Sequences into the New Bacterial Taxonomy. Applied and Environmental Microbiology 73:5261-5267

Wang Y, Kim JH, Mao Z, Ramel M, Pailler F, Perez J, Rey H, Tron S, Jourdan C, Stokes A (2018a) Tree root dynamics in montane and sub-alpine mixed forest patches. Ann Bot 122:861-872

Wang Y, Mao Z, Bakker MR, Kim JH, Brancheriau L, Buatois B, Leclerc R, Selli L, Rey H, Jourdan C, Stokes A (2018b) Linking conifer root growth and production to soil temperature and carbon supply in temperate forests. Plant Soil 426:33-50

Webb CO (2000) Exploring the phylogenetic structure of ecological communities: an example for rain forest trees. The American Naturalist 156:145-155

Yang B, Pang X, Hu B, Bao W, Tian G (2017a) Does thinning-induced gap size result in altered soil microbial community in pine plantation in eastern Tibetan Plateau? Ecology and evolution 7:2986-2993 
Yang Y, Geng Y, Zhou H, Zhao G, Wang L (2017b) Effects of gaps in the forest canopy on soil microbial communities and enzyme activity in a Chinese pine forest. Pedobiologia 61:51-60

Zhang J, Kobert K, Flouri T, Stamatakis A (2014) PEAR: a fast and accurate Illumina Paired-End reAd mergeR. Bioinformatics 30:614-620

Zhang Q, Goberna M, Liu Y, Cui M, Yang H, Sun Q, Insam H, Zhou J (2018) Competition and habitat filtering jointly explain phylogenetic structure of soil bacterial communities across elevational gradients. Environ Microbiol 20:2386-2396

792 